Essay

\title{
ON LISTENING TO THE KULTURKAMPF, OR, HOW AMERICA OVERRULED BOWERS $V$. HARDWICK, EVEN THOUGH ROMER $V$. EVANS DIDN'T
}

\author{
JAY MICHAELSON†
}

\begin{abstract}
INTRODUCTION
Is Bowers v. Hardwick ${ }^{1}$ still good law? It's been fourteen years since the decision upholding Georgia's sodomy law knocked the wind out of the gay rights movement and signaled an end to the expansion of the Supreme Court's substantive due process jurisprudence. Fourteen years, and much has changed: a largely different Court; a subsequent "gay rights case," Romer v. Evans ${ }^{2}$ but also an exponential rise in openly gay television characters, Hollywood celebrities, and politicians; a widespread extension by corporations of family benefits to gay and lesbian domestic partners; and unprecedented public debate on gay marriage, gays in the military, gays at the office, gays just about everywhere. Is the old, quaint reasoning of Bowers still the law of the land?

Upon close reading, I think it is impossible to maintain that the 1996 decision of Romer v. Evans, which voided as unconstitutional a Colorado state constitutional amendment banning gay rights ordinances, overruled Bowers. Different in tone, Romer never mentioned Bowers, the cases rest on different grounds (Romer on the Equal Protection Clause, Bowers on the Due Process Clause), and the laws at

Copyright $(\subset) 2000$ by Jay Michaelson

$\dagger$ Golieb Fellow, New York University Law School. J.D., Yale Law School, 1997; M.A., Hebrew University of Jerusalem, 1998; B.A., Columbia University, 1993. The author thanks the Golieb Fellowship for its support, and Owen Fiss, Joshua Waldman, and Christopher SclafaniRhee for their helpful comments on earlier drafts of this Essay.

1. 478 U.S. 186 (1986).

2. 517 U.S. 620 (1996).
\end{abstract}


issue functioned differently (the Georgia statute in Bowers governed conduct; the Colorado amendment in Romer, status). The Georgia law was deemed valid because it did not interfere with a protected right; the Colorado provision was deemed unconstitutional because it created classes of individuals. These are not contradictory cases; they are complementary. After Romer, Bowers was healthier than ever.

But if we take a fresh look at Bowers in the context of the Court's theories of substantive due process, the case's foundations begin to look quite shaky. Remember that Bowers only deemed "facetious" the argument that homosexual sodomy is a fundamental right after noting that the claim failed a threshold requirement for qualifying as such a right under the Fourteenth Amendmentnamely, a relation to "family, marriage, or procreation." But times have changed since 1986. In 1986, the kulturkampf that Justice Scalia would later describe in his Romer dissent ${ }^{5}$ had not yet begun in earnest; it was hard for Justice White even to imagine a connection between homosexual sodomy and the areas of life traditionally protected by the Fourteenth Amendment. Not so in 2000, a time at which America has thousands of recognized gay families; gay domestic partnerships recognized by corporations and many municipalities; gay adoptive parents; not to mention gay television characters and members of Congress. American culture's definition of the "family" has gradually changed in the last fifteen years to the point where not only is "it difficult to speak of an average American family," as the Court recently noted, ${ }^{6}$ but where the determination of what constitutes a "family" has itself become a matter of debate, and thus, is a protected, personal decision that the state cannot control.

3. Bowers, 478 U.S. at 191.

4. The term kulturkampf, strictly speaking, means a "conflict between civil government and religious authorities especially over control of education and church appointments." Merriam-Webster's Collegiate Dictionary 648 (10th ed. 1993). The original kulturkampf was an attempt by German nationalists led by Otto von Bismarck to crush the growing political power of the Catholic Church. See Jack Balkin, The Constitution of Status, 106 YALE L.J. 2313, 2319 \& n.17 (1997) (citing Gordon A. CRAIG, GERMANY 1866-1945, at 70-78, 280-81 (1978); E.J. PASSANT, A SHORT HISTORY OF GERMANY 1815-1945, at 88-90 (1960); HelMUT WAlser Smith, German Nationalism and Religious Conflict: Culture, IDEOlogy, POLITICS, 1870-1914, at 19-20, 37-50 (1995)). As Balkin has noted, the term has come to be used more loosely as referring to "any struggle between groups over a common national culture." Balkin, supra, at 2319. It is in this wider sense that Justice Scalia-and I-use the term. See infra note 195 (noting the difference between this usage and that of William Eskridge).

5. See Romer, 517 U.S. at 636 (Scalia, J., dissenting).

6. Troxel v. Granville, 120 S. Ct. 2054, 2059 (2000). 
This is not to say that public endorsements of gay families are constitutionally required, or even desirable. Nor is it to say that there is agreement as to what constitutes a "family"-far from it. Rather, the argument is only that the definition of "family," in terms of the way the word is actually used in contemporary society, reasonably may include homosexual couples (and their adopted children), a statement that may not have been true fifteen years ago. As such, a legislature cannot define away gay families by proposing a limiting definition, any more than they can censor political speech by labeling it apolitical; and since gay sexual activity is as important to gay families as straight sex is to straight families, laws that would prohibit such activity are unconstitutional absent a compelling state interest to justify them. All this without any extension of substantive due processa doctrine sprung from a constitutional provision whose elasticity appears to have reached its limit. And all this by the logic of Bowers alone. Precisely because the kulturkampf does matter constitutionally, the premises relied upon by the Court in 1986 are no longer valid today.

In the pages to come, I want to develop this argument and observe where it takes us in our understanding of substantive due process and stare decisis, and, finally, examine the place of "law" in a society where media and popular culture dynamically shape our selfconceptions. Part I analyzes Bowers and Romer, both from a legal and from a sociological-legal perspective, and argues that the two cases do not contradict one another. Part II wades into the miasma of substantive due process, emerges with a few coherent strands of doctrine, and brings to bear the doctrine's emphasis on the family to Bowers, arguing that to define a family right out of existence by unjustifiably limiting the definition of "family" flies in the face of the notion of a protected right and produces an incoherent method of defining constitutional terms. Part II also addresses the Court's doctrine of stare decisis and how it envisions precisely the sort of change that has occurred since Bowers. Finally, I ask in Part III whether any of this matters anymore-whether old, quaint Bowers and its antiquated emphasis on anti-sodomy laws really has any relevance in the days after Ellen, Matthew Shepard, ${ }^{8}$ and Tinky-

7. ABC television series, 1994-98.

8. Matthew Shepard, a 21-year-old student at the University of Wyoming, was lured from a gay bar by two men and subsequently tied to a ranch fence, robbed, pistol-whipped, burned, and left to die after having pleaded for his life; he was discovered 18 hours later, and died after 
Winky. ${ }^{9}$ In particular, I think the collision of popular culture and constitutional jurisprudence helps remind us that, occasionally, law follows society rather than leads it-that sometimes, Tinky-Winky is, and should be, more important than Justice Scalia. The implosion of Bowers in the face of shifting definitions of "family" tells us much about the connections, or disconnects, between law and society; between legal terms and their conventional definitions; and, in the mode of Robert Cover, ${ }^{10}$ among disparate communities that construct values through law. The role constitutional adjudication plays in the evolution of such communities may on occasion be a supporting one, as societal debates render old law seemingly obsolete. Yet sometimes law speaks to popular culture, and sometimes it ought to listen.

\section{BOWERS, ROMER, AND THE SOCIAL MEANING OF CONSTITUTIONAL CASES}

\section{A. Bowers v. Hardwick}

Rarely has so much sprung from so little. The facts of Bowers $v$. Hardwick, to relate them here in their briefest form, were mundane,

five days in a coma. See James Brooke, Gay Man Dies from Attack, Fanning Outrage and Debate, N.Y. TIMES, Oct. 13, 1998, at A1. The brutality of the murder became a rallying point for the opponents of homophobia- even convincing such ardent foes of gay rights as the Rev. Jerry Falwell to urge moderation and mutual respect. See Frank Rich, Journal: Has Jerry Falwell Seen the Light?, N.Y. TIMES, Nov. 6, 1999, at A17 (discussing the Rev. Falwell's reaction to the Matthew Shepard murder).

9. The Teletubbies puppet Tinky-Winky provoked a miniature firestorm of controversy when the National Liberty Journal, a publication run by the Rev. Jerry Falwell, produced "evidence that the creators of the series intend for Tinky-Winky to be a gay role model," to wit: though his voice is "obviously that of a boy," he "is purple — the gay pride color; and his antenna is shaped like a triangle-the gay-pride symbol." Parents Alert (Feb. 1999) <http://www.liberty. edu/chancellor/nlj/feb99/politics2.htm> (on file with the Duke Law Journal). Though the Teletubbies' creators replied that the sexless, non-human characters have no genders-let alone sexual orientations-Rev. Falwell defended the outing of Tinky-Winky by stating that "this is one more in many, many building blocks where we have little boys running around with purses and acting effeminate and leaving the idea that the masculine male, the feminine female is out and gay is OK, which Christians do not agree with." Today (NBC television broadcast, Feb. 11, 1999), quoted in Timothy E. Lin, Note, Social Norms and Judicial Decisionmaking: Examining the Role of Narratives in Same-Sex Adoption Cases, 99 COLUM. L. REV. 739, 739 (1999); see also Lawrie Mifflin, Falwell Takes on the Teletubbies, N.Y. TIMES, Feb. 15, 1999, at C11 (discussing Rev. Falwell's statements and the reaction of a representative of the Teletubbies' television program).

10. Robert Cover concluded that although "formal institutions of the law, and the conventions of a social order are, indeed, important to that world," legal institutions and laws must be "understood in the context of the narratives that give [them] meaning." Robert M. Cover, The Supreme Court, 1982 Term-Foreword: Nomos and Narrative, 97 HARV. L. REV. 4, 4-5 (1983). 
even comically so. Michael Hardwick had been ticketed for public drinking, but failed to appear for his hearing. Georgia police obtained a warrant for his arrest and paid a house call. Entering through an open door, they found Hardwick in flagrante delicto with another gentleman. Both men were arrested for violating Georgia's criminal sodomy statute. ${ }^{11}$ Though the District Attorney decided not to present Hardwick's case to the grand jury, Hardwick sought a declaratory judgment challenging the sodomy law's validity. After a somewhat tricky case history, the Supreme Court granted certiorari and considered Hardwick's claim. ${ }^{12}$

The opinions in Bowers merit close reading. First, and critically, Michael Hardwick was the only respondent in the case. He had originally been joined by a heterosexual couple who claimed to have been "chilled and deterred" from engaging in sodomy by the Georgia law, but they were found to lack standing and did not appeal that decision to the Supreme Court. As Justice White explained in his majority opinion, "The only claim properly before the Court, therefore, is Hardwick's challenge to the Georgia statute as applied to consensual homosexual sodomy. We express no opinion on the constitutionality of the Georgia statute as applied to other acts of sodomy." ${ }^{14}$ This seemingly innocuous point enabled the critical hinge of Bowers's logic: the connection, or lack thereof, between "homosexual sodomy" and "family, marriage, and procreation." Were the case actually just about "sodomy," as the Georgia statute certainly was, and as Justice Blackmun noted in his dissent, ${ }^{15}$ this disconnect would have been harder to defend; sodomy seems not to differ meaningfully from other protected acts of sexual behavior. Moreover, the focus on homosexual sodomy made Bowers into "the gay case," rather than just

11. See Peter Irons, The Courage of Their Convictions: SiXteen Americans Who Fought TheIr WAY to THE Supreme Court 395-96 (1988); see also Mark E. Papadopoulos, Inkblot Jurisprudence: Romer v. Evans as a Great Defeat for the Gay Rights Movement, 7 CORNELl J.L. \& PUB. POL'Y 165, 170 (1997) (stating that the police officer reported seeing Hardwick and another man engage in fellatio). Interestingly, there is some evidence that the public drinking charge was fabricated and that the whole affair was actually a result of police harassment. See IRONS, supra, at 395.

12. See Bowers v. Hardwick, 478 U.S. 186, 189 (1986).

13. Id. at $188 \& \mathrm{n} .2$. Interestingly, Hardwick's partner, with whom he was caught in flagrante, was a closeted, married schoolteacher from North Carolina who begged the police not to tell his wife (or anyone else) and pleaded to lesser charges. See Mary Anne Case, Couples and Coupling in the Public Sphere: A Comment on the Legal History of Litigating for Lesbian and Gay Rights, 79 VA. L. REV. 1643, 1652 (1995).

14. Bowers, 478 U.S. at 188 n.2.

15. See id. at 200 (Blackmun, J., dissenting). 
"the sodomy case"; thus, the dropping of the straight claimants determined Bowers's cultural meaning.

Proceeding from its premise that the case is about "whether the Federal Constitution confers a fundamental right upon homosexuals to engage in sodomy," 17 the Bowers opinion rejects the theory that previous cases about "child rearing and education," "family relationships," procreation, marriage, contraception, and abortion could be read to create "a constitutional right of homosexuals to engage in acts of sodomy." ${ }^{18}$ Why not? Because "[n]o connection between family, marriage, or procreation on the one hand and homosexual activity on the other has been demonstrated, either by the Court of Appeals or by respondent." ${ }^{, 19}$

From this lack of connection flows the rest of the opinion. Once (1) the family, rather than those activities "central to a part of an individual's life," ${ }^{20}$ is defined as the nest of substantive due process rights and (2) family and sodomy are decoupled, the case becomes about whether there is a basis for an independent "right of homosexuals to engage in acts of sodomy" either "implicit in the concept of ordered liberty" ${ }^{\prime 1}$ or, alternatively, among those liberties that are "deeply rooted in this Nation's history and tradition.",2 In other words, because there is no family connection, there must be an independent right - a much harder case for Hardwick to make.

What follows is a notorious lapse in reasoning. Justice White convincingly refutes the notion that a right to sodomy is "deeply rooted in this Nation's history and tradition" by barraging the reader with over five dozen statutory and common-law prohibitions on the act, some dating back to the eighteenth century. ${ }^{23}$ But he then concludes that "to claim that a right to engage in such conduct is 'deeply rooted in this Nation's history or tradition' or 'implicit in the concept

16. See Anne B. Goldstein, History, Homosexuality, and Political Values: Searching for the Hidden Determinants of Bowers v. Hardwick, 97 YALE L.J. 1073, 1102-03 (1988); Janet E. Halley, Reasoning About Sodomy: Act and Identity in and After Bowers v. Hardwick, 79 VA. L. REV. 1721, 1741-45 (1995).

17. Bowers, 478 U.S. at 190.

18. Id. at 191.

19. Id.

20. Id. at 204 (Blackmun, J., dissenting).

21. Id. at 191 (emphasis added) (quoting Palko v. Connecticut, 302 U.S. 319, 325-26 (1937)).

22. Id. at 192 (quoting Moore v. East Cleveland, 431 U.S. 494, 503 (1977) (Powell, J., plurality opinion)).

23. Id. at $193-94$ 
of ordered liberty' is, at best, facetious." ${ }^{24}$ This elision of "history or tradition" and "the concept of ordered liberty" moves anti-sodomy laws from "is" to "ought," from historical practice to the realm of ordered liberty. ${ }^{25}$ It holds that 200 years of a practice magically render it in harmony with the trans-historical concept of ordered liberty, a proposition squarely contradicted by Loving $v$. Virginia, ${ }^{26}$ which declared unconstitutional miscegenation laws that had been on the books in many states since the Founding, by Brown, which likewise changed decades of common practice in the education context, and by common moral intuition. ${ }^{27}$ It also avoids the need for any theoretical discussion about the nature of substantive due process-precisely the subject of several pages of Justice Blackmun's dissent. ${ }^{28}$

Finally, because there is no protected right, Georgia's law need pass only rational basis scrutiny. Anticipating the contours of the Romer debate, Justice White states, without much explanation, that the anti-sodomy law passes rational basis scrutiny because laws are "constantly based on notions of morality." 29 That is, as long as the right affected by a law is not a fundamental one, a "moral" choiceparticularly one made by twenty-five states-is sufficient justification. ${ }^{30}$

In dissent, Justice Blackmun accuses the majority of at least three mistakes of reasoning. First, Blackmun argues, it miscasts the issue at hand from one of "the right to be let alone," or even "to engage in sodomy" generally, to the "right to engage in homosexual sodomy" specifically, thereby misunderstanding the thrust of the substantive due process doctrine. ${ }^{31}$ Second, it conflates the quantity and duration of moral opinions with the validity thereof: "I cannot agree that either

24. Id. at 194 (emphasis added).

25. There is abundant evidence that even on purely historical grounds, Justice White's opinion is factually incorrect. See Goldstein, supra note 16, at 1082-85; Halley, supra note 16, at 1759-67.

26. 388 U.S. 1 (1967).

27. Our country had a long history of slavery, for example, which few would argue does not offend the concept of ordered liberty. See Frank Michelman, Law's Republic, 97 YALE L.J. 1493, 1495-96 (1988) (arguing that tying constitutional thought to "static" ideas of morality would have closed American society off to blacks).

28. See Bowers, 478 U.S. at 203-08 (Blackmun, J., dissenting).

29. Id. at 196.

30. See id. Presumably, some moral judgments are not as stable as "the sodomy laws of some 25 States," although the Court's opinion does not mention what they might be. Chief Justice Burger one-ups the Court in his concurring opinion, by tracing the laws against sodomy to Roman law and Blackstone. See id. at 196-97 (Burger, C.J., concurring).

31. Id. at 199-201 (Blackmun, J., dissenting). 
the length of time a majority has held its convictions or the passions with which it defends them can withdraw legislation from this Court's scrutiny." ${ }^{32}$

Third, and anticipating the question of animus in Romer, Justice Blackmun concludes that "[a] state can no more punish private behavior because of religious intolerance than it can punish such behavior because of racial animus." ${ }^{33}$ For Justice Blackmun, a recourse to vague "morality," however hoary in nature, is insufficient justification for a law, because that "moral" judgment may well spring from an impermissible source. As we will see, this issue will return in Romer and will occupy some of our time in the conclusion of this Essay.

Justice Stevens's little-remarked-upon dissent prefigures Romer even more clearly. Justice Stevens notes that the Georgia statute presents two unconstitutional alternatives: either it applies to everyone, or it must be selectively applied only to homosexuals. In the former case, the statute runs afoul of Carey v. Population Services International, ${ }^{34}$ Eisenstadt v. Baird, ${ }^{35}$ and Griswold v. Connecticut.$^{36}$ In the latter case, "[a] policy of selective application must be supported by a neutral and legitimate interest-something more substantial than a habitual dislike for, or ignorance about, the disfavored group. Neither the State nor the Court has identified any such interest in this case." ${ }^{37}$ For Justice Stevens, the problem is not homosexual sodomy per se, but the lack of a justification for applying the sodomy law at issue against homosexual persons. The Romer shift was not far away.

Clearly, Bowers was tremendously important to the development of substantive due process law and to the trajectory of the gay rights movement in America. Its substantive import was less clear, however. Georgia Code Annotated section 16-2-2(a) ${ }^{38}$ continued to be as unenforced as it had been for the past half-century-even Hardwick's own violation of the statute went unpunished-until, in a curious twist of

32. Id. at 210 (Blackmun, J., dissenting) (citing Roe v. Wade, 410 U.S. 113 (1973), Loving v. Virginia, 388 U.S. 1 (1967), and Brown v. Board of Educ., 347 U.S. 483 (1954)).

33. Id. at 211-12 (Blackmun, J., dissenting).

34. 431 U.S. 678 (1977).

35. 405 U.S. 438 (1972).

36. 381 U.S. 479 (1965).

37. Bowers, 478 U.S. at 219 (Stevens, J., dissenting). Note that Justice Stevens did not take the next step-declaring that it would be unconstitutional to single out homosexuals for discrimination. He stated only that neither the Georgia electorate nor the Georgia legislature had ever expressed an intention to do so. See id. (Stevens, J., dissenting).

38. GA. CODE ANN. § 16-2-2(a) (1984). 
events, the Georgia Supreme Court struck it down as unconstitutional in $1998 .{ }^{39}$ We should not think that sodomy laws are irrelevant; contrary to the myth that sodomy laws are never enforced, some states still prosecute people for breaking them. ${ }^{40}$ Sodomy laws continue to serve as the legal basis for cracking down on men "cruising" for sex in public areas, raids on bars, and refusals to hire "criminals." 41 Still, this is nothing compared with the 1950s and early 1960s, when sodomy laws were strictly enforced, with severe consequences including life sentences in prison, inclusion in registries of sex offenders, and indefinite incarcerations in mental institutions. ${ }^{42}$

More importantly, the act of sodomy itself is, for better or for worse, well out of the closet. Presidential acts of sodomy are discussed in excruciating detail on prime time television. Depictions of the act that would have been shocking a decade ago are now commonplace in movies aimed at teenagers and music videos aimed at anyone. Oprah talks about it. Contemporaneous with the destigmatization of sodomy in popular culture, the battlegrounds of gay rights have shifted away from the bedroom to the office, to the public square, and to a fence in Laramie, Wyoming, where Matthew Shepard was beaten and left to die. If anything, Bowers in the age of Ellen, Will and Grace and Dawson's Creek seems like a relic from the days of Leave it to Beaver.

And yet, Bowers remains an important case in American legal history. It had seemed, until the Court handed down its decision, that striking down the sodomy laws was the next logical step for expanding Fourteenth Amendment rights. Moreover, such a decision would constitute a judicial validation of the $10 \%$ of Americans who are estimated to have broken a law like section 16-2-2(a) at some point in

39. See Powell v. State, 510 S.E.2d 18, 24-26 (Ga. 1998) (holding, by a vote of 6-1, that the statute ran afoul of the Georgia Constitution's Due Process Clause).

40. See Halley, supra note 16, at 1731 n.29 (noting that in 1986, 56 people were incarcerated in Virginia for sodomy without any finding of force or coercion involved); Debbie Nathan, Sodomy for the Masses, THE NATION, Apr. 19, 1999, at 16 (surveying sodomy prosecutions in Texas, Arkansas, and Puerto Rico).

41. See Patricia A. Cain, Litigating for Lesbian and Gay Rights: A Legal History, 79 VA. L. REV. 1551, 1587 (1993); Nathan, supra note 40, at 16. For one local account of sodomy law enforcement, see Laurence Hammack, Rulings Clear Way for Sex Trials: State's Anti-Sodomy Law Used to Prosecute Men Accused of Seeking Sex in Roanoke Parks, ROANOKE TIMES \& WORLD NEWS, May 4, 1999, at B1.

42. See William N. Eskridge, Jr., Democracy, Kulturkampf, and the Apartheid of the Closet, 50 VAND. L. REV. 419, 429-31 (1997). 
their lives. ${ }^{43}$ Instead, Bowers became, and remains, the high-water mark of substantive due process. As Jed Rubenfeld has written, "the Court in [Bowers] necessarily drew a line: the right to privacy stops here." ${ }^{44}$ Bowers is thus arguably the point at which the conservative turn of the Rehnquist Court began, even before Rehnquist began his tenure as Chief Justice.

Bowers was also a major setback for gay activists' litigation strategies and had dramatic ripple effects. ${ }^{45}$ In the years following Bowers, courts across the country declined to find constitutional violations in "gay rights" cases, often reasoning that because sodomy could be criminalized, discrimination against sodomizers was constitutional. ${ }^{46}$ More significantly, the hoped-for legitimization of gay rights stalled for years, with political consequences ranging from the "Don't Ask, Don't Tell" policy for gays in the military, which has in fact led to a dramatic increase in Pentagon investigations and expulsions of lesbians and gay men, to the "Defense of Marriage

43. Ten percent is the figure frequently cited as the percentage of homosexual men in the U.S. population, a figure derived from a study conducted in the 1940s by Alfred Kinsey. See generally Alfred C. Kinsey et AL., SeXual Behavior in the Human Male (1948). This figure has been consistently attacked as inaccurate. See, e.g., Joseph P. Gudel, Homosexuality: Fact and Fiction (visited June 6, 2000) <http://www.christiandemocratic.org.au/fed/mirrors/ hmsex_illness.htm> (on file with the Duke Law Journal) (arguing that Kinsey's study contained flawed methodology and conclusions). Nevertheless, it is still consistently cited. See, e.g., Elsa Brenner, The Invisible Population, The Gays Next Door: At Work, Home and School, a Minority Often Under Attack, N.Y. TIMES, Nov. 14, 1999, § 14 (Magazine), at 1, 15 ("[I]t is estimated that about 10 percent of the population is gay.").

44. Jed Rubenfeld, The Right of Privacy, 102 HARV. L. REV. 737, 747 (1989).

45. See Cain, supra note 41, at 1617-40; Mary C. Dunlap, Gay Men and Lesbians Down by Law in the 1990's USA: The Continuing Toll of Bowers v. Hardwick, 24 Golden GATE U. L. REV. 1, 11-12 (1994).

46. See, e.g., Shahar v. Bowers, 114 F.3d 1097, 1105-11 (11th Cir. 1997) (allowing Georgia's Attorney General to fire a lesbian because she might have a propensity to engage in sodomy, creating a "bad appearance" for the Attorney General and a conflict of interest in enforcing sodomy laws); Woodward v. United States, 871 F.2d 1068, 1076 (Fed. Cir. 1989) (upholding a Navy discharge of a gay seaman because "[a]fter Hardwick it cannot logically be asserted that discrimination against homosexuals is constitutionally infirm"); see also Courtney G. Joslin, Equal Protection and Anti-Gay Legislation: Dismantling the Legacy of Bowers v. Hardwick, 32 HARV. C.R.-C.L. L. REV. 225, 227-29 (1997) (asserting that Bowers "has come to stand for the principle that discrimination against homosexuals is constitutionally permissible"); Sherene D. Hannon, Casenote, License to Oppress: The Aftermath of Bowers v. Hardwick is Still Felt Today: Shahar v. Bowers, 19 PACE L. REV. 507, 537-39 (1999) (arguing that after Bowers, gay litigants asserting civil rights claims are disadvantaged because of the legal inferences that are made from their homosexual status).

47. See Robert D. Dodson, Homosexual Discrimination and Gender: Was Romer v. Evans Really a Victory for Gay Rights?, 35 CAL. W.L. REV. 271, 292-300 (1999); Kenji Yoshino, Assimilationist Bias in Equal Protection: The Visibility Presumption and the Case of "Don't Ask, 
Act." ${ }^{48}$ It would be hard to conceive of such measures taking effect in the wake of a Bowers opinion that found sodomy to be a protected activity and gays to be a protected class.

Most importantly, although perhaps most difficult to fit into a doctrinal box, Bowers represented a clear moral statement on the part of the Supreme Court, and endorsed a set of value judgments about gays and lesbians. The long list of anti-sodomy laws cited by Justice White cannot but be read as a not-so-tacit endorsement of those laws' contents. After all, they are the "proof" that there is no fundamental right to sodomy inherent in history, tradition, or the concept of liberty itself. Imagine what sort of moral impact Loving would have had if it had upheld the miscegenation law at issue, and had listed the dozens of miscegenation laws on the books as "proof" that the values behind the Virginia statute were, in fact, foundational American beliefs. ${ }^{49}$ Even if the miscegenation laws were never enforced, the marginalization of their opponents would have changed the character of the civil rights movement. Rather than having the imprimatur of the legal establishment behind it, the movement would be cast as opposed to foundational American values, and as promoting an agenda fundamentally at odds with the will of sixteen states (as of 1967). Loving decided in this way would have provided tremendous social artillery to the opponents of school integration and civil rights laws, and would have cast the separation of the races as the product of mainstream American beliefs.

I believe it is in this rather ill-defined sociological arena that the true significance of Bowers lies. Bowers defined the mainstream and the margins, just as cases like Loving and Brown had done by defining themselves in terms of larger claims of equality and freedom. Only this time, the "crusaders for civil rights" were "facetious" and the status quo was part of history, tradition, and liberty. This definition of mainstream and margin was the Supreme Court's authorita-

Don't Tell”, 108 Yale L.J. 485, 545-47 (1998); C. Dixon Osburn \& Michelle M. Benecke, Conduct Unbecoming Continues: The First Year Under "Don't Ask, Don't Tell, Don't Pursue” (1995) $<$ http://www.sldn.org/scripts/sldn.ixe?page=article_0001> (on file with the Duke Law Journal).

48. Pub L. No. 104-199, 100 Stat. 2419 (1996).

49. Justice Stevens noted the analogy between miscegenation laws and anti-sodomy laws in his dissent from Bowers. See Bowers v. Hardwick, 478 U.S. 186, 216 (1986) (Stevens, J., dissenting). 
tive statement on what Justice Scalia would later call the kulturkampf of sexual orientation in America.

Perhaps it is not surprising, then, that when Romer v. Evans first appeared, it was seen as in some way "overruling Bowers." show, I think this claim is $90 \%$ inaccurate from a legal point of viewthe only part of Bowers clearly overruled by Romer was Justice White's parting statement that "morality," undefined, unquestioned, and unexplained, is a legitimate basis for law. Culturally, however, Romer did send a very different message about gays in America; culturally, the argument that Bowers was overruled may not be so off the mark.

\section{B. Romer v. Evans}

In contrast to the private origin of Bowers, Romer v. Evans began in the public square, full of sound and fury. Disturbed by provisions in the municipal codes in Aspen and Boulder, Colorado, some of which had been in place for twenty years, the people of Colorado voted in 1992 for a referendum known as "Amendment 2." The amendment prohibited any state or municipal agency from adopting any "statute, regulation, ordinance or policy whereby homosexual, lesbian or bisexual orientation, conduct, practices or relationships shall constitute or otherwise be the basis of ... minority status, quota preferences, protected status or claim of discrimination." ${ }^{, 52}$ Amendment 2, then, was not an affirmatively discriminatory law (as in Bowers) but a negatively discriminatory one-this was a constitutional amendment that denied protection to gays, bisexuals, and lesbians, but appeared not to inflict any particular hardship. As with Bowers, though, the Court's characterization of the law at issue was crucial.

50. Indeed, Michael Bowers himself, the Attorney General of Georgia who was the named petitioner in Bowers, subsequently tried to make a career out of being "that Bowers" in his failed bid in Georgia's 1998 gubernatorial election. See Geraldine Baum, Appetite for Scandal Altering Political Menu, L.A. TIMES, Jan. 10, 1999, at A1. Bowers's candidacy failed, apparently, due to the revelation that the self-styled "crusader for sexual morality" had carried on a tenyear affair with his secretary. See id.

51. See, e.g., Louis Michael Seidman, Romer's Radicalism: The Unexpected Revival of Warren-Court Activism, 1996 SUP. CT. REV. 67, 102 (1996) (claiming that Romer "went beyond a mere overruling of Bowers" by "reviving local antidiscrimination measures").

52. COLO. CONST. art. II, § 30b (1993), quoted in Romer v. Evans, 517 U.S. 620, 624 (1996). For a discussion of Romer and its case history prior to the Supreme Court, see Dodson, supra note 47, at 273-79; Joslin, supra note 46, at 230-33. 
Justice Kennedy, writing for a six-Justice majority, ${ }^{53}$ saw the amendment not as putting everyone "in the same position," as Colorado insisted, but as putting homosexuals "in a solitary class with respect to transactions and relations in both the private and governmental spheres" ${ }^{54}$ because "[h]omosexuals are forbidden the safeguards that others enjoy or may seek without constraint."

Ordinarily, the next step would be to determine the standard of review. But in Romer, Justice Kennedy never examined whether or not sexual orientation is a "suspect classification," instead proceeding directly to the application of rational basis scrutiny-ultimately finding Amendment 2 to fail even under that deferential standard of review. Accordingly, there are two ways to read Romer on this point. On the one hand, it can be read as announcing that sexual orientation is not a suspect classification like race, and so only rational basis scrutiny need be applied. On the other hand, it might be read as only stating that since Amendment 2 fails even rational basis scrutiny, there is no need to decide whether a higher level of scrutiny is warranted. This ambiguity avoids the thorny issue of status in a case that does not require the decision-indeed, it may have helped get the 6-3 majority-but it does lead to the sort of indeterminacy that we now face. ${ }^{56}$

The remainder of the Romer reasoning consists of two steps. First, Justice Kennedy labeled Amendment 2 as "at once too narrow and too broad" because it "identifies persons by a single trait and then denies them protection across the board." ${ }^{, 57}$ Second, by dint of that overbreadth, Amendment 2 raises "the inevitable inference that the disadvantage imposed is born of animosity toward the class of

53. Bowers was a 5-4 decision, written by Justice White, and joined by Chief Justice Burger and Justices Powell, Rehnquist, and O'Connor in the majority. Justices Brennan, Marshall, Blackmun, and Stevens were in dissent. Romer's majority consisted of Justices Stevens, O'Connor, Kennedy, Souter, Ginsburg, and Breyer; Chief Justice Rehnquist joined Justices Scalia and Thomas in dissent. Justice Powell said after he retired that he "probably made a mistake" by siding with the Bowers majority. See JOHN C. JEFFrIES, JR., JUSTICE LEwIS F. POWELL, JR. 530 (1994).

54. Romer, 517 U.S. at 627.

55. Id. at 631 .

56. On heightened scrutiny for gays and lesbians, see Kenji Yoshino, Suspect Symbols: The Literary Argument for Heightened Scrutiny for Gays, 96 CoLUM. L. REV. 1753, 1753 (1996); see also Barbara J. Flagg, "Animus" and Moral Disapproval: A Comment on Romer v. Evans, 82 MinN. L. REV. 833, 834 (1998) (noting that rational basis review "seemingly requires more, rather than less, judicial involvement with controversial value choices").

57. Romer, 517 U.S. at 633. 
persons affected." ${ }^{58}$ While agreeing that "even laws enacted for broad and ambitious purposes can be explained by reference to legitimate public policies," 59 Justice Kennedy rejected Colorado's arguments that Amendment 2 was about "respect for other citizens," "freedom of association," or "conserving resources to fight discrimination against other groups," because, he argued, the broad nature of Amendment 2 itself belies such claims. ${ }^{60}$ In other words, while it might be possible for a broad law to have a rational basis, Amendment 2's breadth is so wide as to strongly suggest that only "animus" can explain it. ${ }^{61}$

This "animus" is the hinge of Justice Scalia's furious dissent. ${ }^{62}$ For Justice Scalia, to label as "animus" what may well be a reflective moral choice on the part of the Colorado populace is both inconsistent with Supreme Court precedent and a flight of interpretive hubris. In the first place, Justice Scalia claims that Bowers clearly stands for the proposition that it is okay to treat homosexuals unequally from heterosexuals, because Bowers upheld a law making "the conduct that defines the class criminal." "If it is rational to criminalize the conduct," he reasons, "surely it is rational to deny special favor and

58. Id. at 634 .

59. Id. at 635 .

60. Justice Kennedy noted:

The primary rationale the State offers for Amendment 2 is respect for other citizens' freedom of association, and in particular the liberties of landlords or employers who have personal or religious objections to homosexuality. Colorado also cites its interest in conserving resources to fight discrimination against other groups. The breadth of the amendment is so far removed from these particular justifications that we find it impossible to credit them.

Id. at 635 .

61. It is worth noting that this was not the theory of the Romer plaintiffs, who had alleged that Amendment 2 violated the right of equal participation in the political process, and who had won on those grounds below. See Evans v. Romer, 882 P.2d 1335, 1341 (Colo. 1994); Evans v. Romer, 854 P.2d 1270, 1282 (Colo. 1993) (both decided on equal protection grounds); see also Flagg, supra note 56, at 838-40 (discussing generally the plaintiffs' original arguments against Amendment 2). The reasoning in Romer appears to have been based on an amicus brief submitted by Laurence Tribe, John Hart Ely, Gerald Gunther, Philip Kurland, and Kathleen Sullivan. See Akhil Reed Amar, Attainder and Amendment 2: Romer's Rightness, 95 MICH. L. REV. 203, $204 \&$ n.6 (1996). On the impermissibility of animosity as a legislative justification, see, for example, City of Cleburne v. Cleburne Living Ctr., Inc., 473 U.S. 432, 448 (1985), and United States v. Moreno, 413 U.S. 528, 534 (1973).

62. Romer, 517 U.S. at 636 (Scalia, J., dissenting). Justice Scalia was joined in dissent by Chief Justice Rehnquist and Justice Thomas.

63. Id. at 641 (Scalia, J., dissenting) (quoting Padula v. Webster, 822 F.2d 97, 103 (D.C. Cir. 1987)). The dissent also argues that Amendment 2 only prohibits preferential treatment for homosexuals, and thus does not place a special disability on them. See id. at 638 (Scalia, J., dissenting). 
protection to those with a self-avowed tendency or desire to engage in the conduct. ${ }^{, 64}$ Second, Justice Scalia states that animus against an activity many may find morally repugnant is a legitimate response; for Justice Scalia, the people of Colorado are "entitled to be hostile toward homosexual conduct," and thus to people likely to engage in it, ${ }^{65}$ just as they may be hostile to alcoholics, drug addicts, or those of a polygamous "orientation." "Amendment 2 was thus a "reasonable" response by the majority to a politically powerful minority that the Court should not second guess out of "political will.",

At the heart of the doctrinal debate between Justice Scalia and Justice Kennedy, then, is the reason for Colorado's action. Both seem to agree that considered moral judgment is a permissible basis for a law (under rational basis scrutiny) but that "animus" is not; the question is which is present in Amendment 2. For Justice Kennedy, the overbreadth of Amendment 2 means animus is the only conceivable explanation for it. But while Justice Scalia says the majority has "mistaken" the "Kulturkampf for a fit of spite, ${ }^{\circ 6}$ he does not provide a basis for how to decide which is which. ${ }^{69}$ Justice Scalia says that gay people, like polygamists, cause a "perceived social harm." ${ }^{, 70}$ But how is this "perception" to be evaluated without peering behind the veil of moral judgment? Amendment 2's purpose-"to prevent piecemeal deterioration of the sexual morality favored by a majority of Colora-

64. Id. at 642 (Scalia, J., dissenting). Justice Scalia further argues that even if there are gay people who, for whatever reason, do not engage in criminalizable gay sex, that does not mean that the statute cannot ever be applied in a valid way to those who do. See id. at 643 (Scalia, J., dissenting).

65. Id. at 644 (Scalia, J., dissenting).

66. Id. at 648 (Scalia, J., dissenting). Note that all but one of the examples which Justice Scalia cites are of statutes that prohibit the relevant conduct-consuming alcohol, using drugs, polygamy; they do not set up a "class of persons" disfavored not only with respect to the offensive activity but with regard to housing, or insurance, or any of the other areas of human life which Justice Scalia himself cites. Only one act, the disenfranchisement of polygamists, approved by the Court in Davis v. Beason, 133 U.S. 333, 348 (1890), approaches such a disability.

67. Romer, 517 U.S. at 645-46, 653 (Scalia, J., dissenting).

68. Id. at 636 (Scalia, J., dissenting).

69. See S.I. Strong, Justice Scalia as a Modern Lord Devlin: Animus and Civil Burdens in Romer v. Evans, 71 S. CAL. L. REV. 1, 9-10 (1997) (comparing Justice Scalia's arguments with those of Lord Patrick Devlin, who supported the continuation of British anti-sodomy laws on moral grounds). Unlike Scalia, Devlin set up a series of additional requirements before morality could be used to justify a law, among them some degree of unanimity and "patient and deliberate decisionmaking." Id. at 11-13. This would appear to distinguish his approach from Justice Scalia's, insofar as it inquires into the substance and procedure of moral reasoning itself, rather than accepting the output of that reasoning process as ipso facto legitimate.

70. Romer, 517 U.S. at 651 (Scalia, J., dissenting). 
dans", —is, without more, no more "rational" a purpose than "to prevent piecemeal deterioration of the racial purity favored by a majority of South Carolinians" in Loving, or, if that is too strong, "to prevent piecemeal deterioration of the sexual morality favored by a majority of South Carolinians." Surely there must be some explanation of the moral choice itself, or at least of its process, in order for the moral choice to be considered reasonable. Simply calling a choice moral, and linking it with vague references to scriptural or other religious traditions, is an insufficient explanation.

In sum, I am mystified by Akhil Amar's report that with regard to constitutional scholars, the initial consensus was that "Justice Kennedy won their hearts; Justice Scalia, their heads." ${ }^{, 72}$ Notwithstanding Justice Scalia's parsing of nondiscrimination principles, it is his opinion, not Justice Kennedy's, which makes the emotional plea in Romer, albeit a plea to emotions other than those of liberal constitutional law scholars. "Moral judgment" is, without more, an intellectually vapid term, though one with emotional punch, that masks philosophical, social, theological, intuitional, or psychological conclusions about a given subject. At least the Romer majority explains why it deems Colorado's motive to be animus-the radical overbreadth of the law. ${ }^{73}$ Conceivably, moral disapproval that supported a law reasonably related to that disapproval might not be "animus" in the constitutionally infirm sense; a clear policy choice reflecting a moral vision is clearly distinguishable from a ban on "gay rights" so overbroad that it cannot possibly reflect a reasoned moral judgment. $^{74}$

71. Id. at 653 (Scalia, J., dissenting).

72. Amar, supra note 61, at 204.

73. See Romer, 517 U.S. at 635.

74. Amar argues that Justice Kennedy's repeated framing of Romer in terms of named classes and special disabilities suggests a deeper meaning of the Equal Protection Clause. Amar refers to this meaning as the "attainder principle," a generalization from the constitutional bar on a law targeting one named person to a bar on laws targeting a named group of persons, and argues that this is the real basis of Romer. See Amar, supra note 61, at 208-20, 223-28; see also Daniel Farber \& Suzanna Sherry, The Pariah Principle, 13 CONST. COMMENT. 257, 258 (1996) (arguing that Romer is undergirded by the principle that "forbids the government from designating any societal group as untouchable"). But as Amar says, "Not all laws that name suffer this fatal flaw-only those that, in Kennedy's words, reflect 'animus towards the class." Amar, supra note 61, at 226 (quoting Romer, 517 U.S. at 634). In other words, it is not only targeting the single named group itself that is essential, but targeting-plus-animus. But given that traditional bills of attainder might have been passed not because of animus but for very rational reasons-treason, for example-it is unclear that the principles undergirding the Attainder Clause are really the driving force here. 
Such subtleties were largely eclipsed by the seemingly tolerant tone of the Romer opinion, a case that has come to stand for a social proposition - that animus against homosexuals is to some extent illegitimate-as much as a legal-doctrinal one. ${ }^{75}$ In the words of one gay rights activist, "[i]n Romer, the court turned an important corner and recognized that gay men and lesbians in this country have legitimate claims for equality.... That's an important tone to set for the Congress, state legislatures and courts around the country." ${ }^{, 6} \mathrm{Or}$, in the words of another activist, writing just before the Romer decision,

the tone of Bowers was not lost on the nation. Many Americans see the Supreme Court as something of a constitutional conscience for the country. The message of Bowers was that there is nothing immoral about raw hostility to lesbians and gay men. If the Court... embraces that basic American notion of a level playing field in politics and upholds the Colorado Supreme Court, the public debate about lesbians and gay men is likely to change significantly, and become much more open to our plea for equal treatment. ${ }^{77}$

Though, in fact, the judicial success rates for "gay rights" cases since Romer have been decidedly mixed, at the core of Romer is a conclusion similar to that mainstream-and-margin-defining move in Loving:

75. Professor Amar reads Justice Kennedy's opinion as cognizant of this fact, and "written for fellow citizens." Amar, supra note 61, at 221. On the impact of Romer and post-Romer litigation, see generally Andrew M. Jacobs, Romer Wasn't Built in a Day: The Subtle Transformation in Judicial Argument over Gay Rights, 1996 WIS. L. REV. 893 (1996) (suggesting that Romer signals a shift in the way American law conceives of gays and characterizes questions of gay rights); Andrea M. Kimball, Note, Romer v. Evans and Colorado's Amendment 2: The Gay Movement's Symbolic Victory in the Battle for Civil Rights, 28 U. TOL. L. REV. 219 (1996). Robert Dodson disputes the conclusion that Romer really was much of a victory after all, noting that because Romer did not require heightened scrutiny, and because Bowers remained good law, the case has offered little protection for homosexuals. See Dodson, supra note 47, at 289-311.

76. Joan Biskupic, For Gays, Tolerance Translates to Rights, WASH. Post, Nov. 5, 1999, at A24 (quoting Mary Bonauto, the Civil Rights Director of Gay and Lesbian Advocates and Defenders) (internal quotation marks omitted).

77. Matt Coles, In Romer v. Evans, the Gay Rights Movement Nears a Crossroad (last modified Sept. 27, 1995) <http://www.aclu.org/news/n092795b.html> (on file with the Duke Law Journal). In this statement, Coles, the Director of the ACLU National Lesbian and Gay Rights Project, expressed his concern over the Supreme Court's ability to influence public morality. See id.

NOW Action Vice President Rosemary Dempsey said of Bowers: "This decision makes it clear that homophobia is not a valid justification for the government to discriminate." Kimberlee Ward, Supreme Court Victory Protects Lesbian/Gay Rights, National NOW Times (last modified Oct. 1996) <http://www.now.org/nnt/11-96/lesbian.html> (on file with the Duke Law Journal). 
that "animus against homosexuals" is no longer in the mainstream. In cultural terms, Romer largely overruled Bowers.

\section{Reconciling Bowers and Romer}

But in strictly legal terms, Romer v. Evans did not overrule Bowers v. Hardwick. It never mentioned Bowers, it did not impliedly or expressly void the statute upheld in Bowers, and it was only connected to Bowers by a commonality of subject matter. Yes, Romer was a new Supreme Court statement on the constitutional implications of sexual orientation, and it seemed to have a certain tone of tolerance. But lawyers do not generally suppose that, say, a recent free speech case overrules a previous one simply because it departs in some way from some strand of implicit reasoning in the earlier decision or has a different tone. In fact, although it would be reasonable to suppose that Bowers is something less than perfectly good lawsurely Romer changes the landscape somewhat-I will show in this section that the extent to which Romer actually overturns Bowers is extremely limited. Romer did not occlude Bowers; it circumscribed it-a judicial move that validates what goes on within the drawn circle even as it excludes that which is beyond it.

The first and clearest distinction between Romer and Bowers is precisely that which Justice Scalia sought to elide in his Romer dissent: the difference between conduct and status, a distinction which has been the subject of gay and lesbian litigation for years. ${ }^{78}$ Bowers allowed the prohibition of a given act because the right to engage in that act was not protected by the Constitution. Romer, on the other hand, invalidated an amendment that sought to allocate rights on the basis of membership in a particular group, and even though the group itself was not necessarily deserving of extra protection (i.e., homosexuals were not seen to be a suspect class), the very act of sorting citizens itself required some rational basis, which Amendment 2 could not provide.

The obvious response to this is that the "rational basis" of Amendment 2 is none other than that of Bowers: a moral disapproval of homosexual sodomy, plus an inference that "avowed" homosexuals are likely to engage in gay sex. However much Justice Scalia's definition of homosexuals as "likely criminals" may make some of us likely criminals cringe, surely he has a point. Assuming sodomy is a crime,

78. See Cain, supra note 41, at 1570-71. 
then gay men and lesbians are precisely those persons who identify themselves by their propensity to commit a crime. If the criminalization of sodomy withstands constitutional scrutiny, surely this next, modest step-proscribing certain rights of likely criminals-must as well. ${ }^{79}$

This conduct/status linkage misses at least two critical points, however: first, it has too narrow a view of gay identity to shift the focus from status to conduct sufficiently; and second, eliding the distinction between conduct and status overlooks the real lynchpin of the Court's opinion in Romer: the overbreadth of the Amendment. First, it should go without saying that reducing gay men and lesbians to "likely criminals" offers a very pale rendition of gay identity. ${ }^{80}$ Whatever Justice Scalia would like to think, reams of scholarship make it indisputable - as a matter of fact, not opinion - that being gay means much more than engaging in the act of sodomy. Ironically, the Colorado Amendment's very language seems to take this position. Amendment 2 makes clear that it applies not only to the "conduct" of gay sex but to "homosexual, lesbian or bisexual orientation" as well. ${ }^{81}$ If being gay is only, or at least constitutively, about being a likely sodomizer, then why the interest in homophobic circles in gay political activity, gay teachers, the "gay lifestyle"? Is "lifestyle" just a code word for sex? Surely, if cultural attacks against non-sexual homosexuals (Tinky-Winky comes to mind) are to make any sense at all, there must be something more to gay people than sex, even in a "right wing" view. ${ }^{82}$ And legally, insofar as Amendment 2 discriminates at

79. See Equality Found. of Greater Cincinnati, Inc. v. City of Cincinnati, 54 F.3d 261, 267 (6th Cir. 1995) ("[F]or purposes of these proceedings, it is virtually impossible to distinguish or separate individuals of a particular orientation which predisposes them toward a particular sexual conduct from those who actually engage in that particular type of sexual conduct.") (emphasis added); Steffan v. Perry, 41 F.3d 677, 689-90 (D.C. Cir. 1994). State-sponsored discrimination that is upheld by the Supreme Court hardly seems invidious, as it is officially acknowledged and approved. See Padula v. Webster, 822 F.2d 97, 103 (D.C. Cir. 1987) ("After all, there can hardly be more palpable discrimination against a class than making the conduct that defines the class criminal.").

80. On the equation of homosexuality with sodomy, see Anne B. Goldstein, Reasoning about Homosexuality: A Commentary on Janet Halley's 'Reasoning about Sodomy: Act and Identity in and After Bowers v. Hardwick', 79 VA. L. REV. 1781, 1789-94 (1993); Halley, supra note 16 , at 1722 .

81. COLO. ConST. art II, § 30b (1996), quoted in Romer v. Evans, 517 U.S. 620, 624 (1996).

82. On the fluidity of the act/identity distinction in this context, see generally Halley, supra note 16. Halley has since noted that the distinction has served as an important rhetorical lever in the debates about lesbians and gays in the military. See Janet E. Halley, The Status/Conduct Distinction in the 1993 Revisions to Military Anti-Gay Policy: A Legal Archeology, 3 GAY L.Q. 159, 164 (1996). 
all, it discriminates as much against the "non-practicing" homosexual as against the "practicing" one. In this regard, Amendment 2 really is about status rather than conduct: one can be a lesbian widow or sexually inactive gay man and still be discriminated against by Amendment 2 .

To focus on some strange species of "non-sodomizing homosexual" may seem quite peculiar. Yet, as far as the Scalia view is concerned, the "fit" between gays and likely criminals is absolutely essential. So let's take the "non-sodomizing homosexual" seriously for a moment, and consider the overbreadth of Romer. Let us entertain the notion that biology is destiny, and that sexual orientation is as much a feature of the human body as eye or skin color. If this is so, then a man may be gay whether he engages in sodomy or not. However, our hypothetical gay man is also a law-abiding citizen to the core-sort of a Dudley Do-right in drag. Dudley identifies as a gay man, because after all he is Dudley Do-right and will not lie about his nature. But at the same time, Dudley carefully abstains from those acts of sodomy which the majority of his state has decided to criminalize. Can he still be fired from his job merely for being honest about his sexual orientation?

The non-criminal homosexual does not fall within Justice Scalia's formulation-hence the importance of his point that Romer was a facial challenge ${ }^{83}$-yet Amendment 2 goes out of its way to mention orientation as well as conduct, practices, and relationships. Applying ordinary canons of statutory construction (indeed, with a pro-Scalia textualist bias), it is clear that Amendment 2 stands for the principle that one can be of homosexual orientation without engaging in homosexual conduct-why else would it list both? The language of the statute directly implicated a class of people and failed equal protection in being so directed. So both Bowers and Romer can be right.

This last point brings up the constitutional doctrinal parallel to the factual difference between conduct and status: a law implicating substantive due process, which is act-focused, and one implicating equal protection, which is person-focused. And while it may be very difficult for an act to fall within the tight zones of substantive due process jurisprudence, the very act of sorting people into classes raises equal protection hackles. In homiletical terms, the difference

83. See Marc E. Isserles, Overcoming Overbreadth: Facial Challenges and the Valid Rule Requirement, 48 AM. U. L. REV. 359, 441 n.371 (1998) (critiquing Scalia's argument on the basis that it ignores the constitutional basis of the Court's holding in Romer). 
cleaves along the adage of "Hate the Sin, but Love the Sinner"-a potent phrase, with its roots in Augustine, that many have used to gloss the coexistence of Bowers and Romer ${ }^{84}$ Hating the sin, i.e., prohibiting sodomy, may be permissible on the basis of "sexual morality," because only a limited set of acts is protected by the Due Process Clause. Hating the sinner, on the other hand, is a harder row to hoe, because any law that sorts people into classes may run afoul of the Equal Protection Clause, as well as deeper notions of anti-caste equality in a constitutional democracy, and it is harder to construct a rational basis for such a broad segregation. ${ }^{85}$

Moreover, as Cass Sunstein points out-prior to Romer, but with Bowers particularly in mind-the Due Process and Equal Protection Clauses have fundamentally different purposes within the Constitution. ${ }^{86}$ The Due Process Clause, Sunstein argues, is essentially retrospective and is meant to protect society's basic core values. The Equal Protection Clause, on the other hand, was designed to eliminate practices that existed at the time of ratification and is intended to protect unpopular minority groups. ${ }^{87}$ Consequently, it is entirely possible for a ban against a traditionally proscribed activity to coexist constitutionally with protection for the class of people who engage in that activity. $^{88}$

Thus, even for the gay man who practices sodomy, the Amendment covered too much of his status. Had Amendment 2 stated, "No gay man or woman can be a school guidance counselor," it might have passed Romer's muster, because the prohibition, however odious, is narrow enough that the basis for it might be a legitimate desire not to inculcate "gay values" (whatever that might mean) in children.

84. Augustine actually said, "Cum dilectione hominum et odio vitiorum," literally, "With love for mankind and hatred of sins." THE OXFORD DICTIONARY OF QUOTATIONS 37(8) (4th ed. 1992). On the maxim's relationship to Romer, see Jacobs, supra note 75, at 968 (questioning whether prohibitions on sodomy distinguish between the act and the individual).

85. See Kenneth L. Karst, Citizenship, Race and Marginality, 30 WM. \& MARY L. REV. 1, 2 (1988) (concluding that "Americans have always embraced the ideal of equal citizenship" even as they have "tolerated the subordination of groups").

86. See Cass Sunstein, Sexual Orientation and the Constitution: A Note on the Relationship Between Due Process and Equal Protection, 55 U. CHI. L. REV. 1161, 1168-69 (1988) [hereinafter Sunstein, Sexual Orientation]. This appears to be an evolution from Sunstein's earlier position that it might be possible to unify these and other Clause-based prohibitions in the Constitution under the rubric of "naked preferences." Cass Sunstein, Naked Preferences and the Constitution, 84 Colum. L. REV. 1689, 1692-93 (1984) [hereinafter Sunstein, Naked Preferences].

87. See Sunstein, Sexual Orientation, supra note 86, at 1170-74.

88. See id. at 1174-75. 
How about, "No gay man may be a soccer coach"? Harder to say. But it is still miles away from Amendment 2 itself, which prohibited all kinds of discrimination claims by gays, including those in contexts where sexuality has absolutely nothing to do with the matter at issue-employment at a construction site or a fast-food restaurant, for instance.

In summary, Bowers and Romer are not in contradiction; they may indeed be seen as complementary, notwithstanding their apparent difference in tone towards the persons affected by the laws under review. Moreover, since Romer never mentions Bowers, it would be presumptuous to read into its silence an intent to overrule a previous Supreme Court precedent not on all fours with the case at bar. Therefore, in a strict legal sense, Bowers was not thus overthrown.

\section{BowERS A GONISTES: ANTI-SODOMY LAWS, SubSTANTIVE DUE PROCESS, AND "FAMILY VALUES"}

In all the doctrinal hair-splitting surrounding Romer and Bowers, it is easy to lose one's way and take for granted certain premises of the entire project. We can easily forget how the Court got to the odd crossroads of allowing anti-sodomy laws but not allowing anti-gayrights measures, and that, but for Justice Powell's swing vote, the landscape would have looked utterly different, with a right to conduct one's sex life simply the next, logical step in the progression of substantive due process jurisprudence. We might also forget that Georgia's sodomy law was never subject to strict scrutiny, because Justice White did not locate a right to sodomy within either Supreme Court precedent or the Court's dominant theories of substantive due process generally. I now wish to return to that point and consider the locus of homosexual sodomy within the geography of existing Supreme Court precedent on substantive due process.

The argument of this part is as follows. Even if we construe substantive due process cases relatively narrowly (and the last decade of Supreme Court jurisprudence on the subject says that we must), cases decided by the Court in the last forty years clearly state that the Fourteenth Amendment prohibits government interference with certain core, fundamental liberties. Even within the restrictive boundaries set by the Court in recent years, "the relationships that develop within the unitary family" are the core of the protected liberties. ${ }^{89}$

89. Michael H. v. Gerald D., 491 U.S. 110, 123 (1989) (Scalia, J., plurality opinion). 
In 1986, it was plausible to state that "[n]o connection between family, marriage, or procreation on the one hand and homosexual activity on the other" could be shown to exist. ${ }^{90}$ But now, a decade and a half later, the statement is no longer credible. Gradual, bitterly contested changes in American family life, which fall squarely within the exceptions to stare decisis as delineated by the Court's jurisprudence, require us-without regard for our personal opinions on the subjectto see the homosexual family as a species of the American family as a matter of sociological fact. Thus, while the Court need not, and should not, force a particular definition of "family" on Congress and state legislatures, the right of gay families to define themselves as "families" must be protection of the family if such protection is to have any meaning.

Under such a theory, it may yet be permissible for states-to choose but one recently controversial example-to bar gay marriage. There may (and should) be continued public soul-searching over whether these new families deserve other forms of official state recognition, because there is a difference between recognizing that such families may exist and placing state imprimaturs of approval on them. But because gay families do exist, they must, as dictated by the last forty years of substantive due process precedent, be permitted to engage in their constitutive activities. As such, the nexus that was missing in Bowers is now present: the link between gay sexual activity and the family is as easy to demonstrate as that between straight sexual activity and the family. And once that link is made, strict scrutiny applies to laws governing, inter alia, sodomy—not by any extension of doctrine, but by simple application of conservative doctrine to the facts. As it is very hard to see what compelling state interest is served by sodomy laws, Bowers falls, not because of court cases or legal theories, but because of history.

In the first section of this part, my goals are to delineate briefly a conservative understanding of substantive due process and to show how that doctrine protects activity related to the family. Although this necessarily requires an unfortunate wade into the miasma of substantive due process law, we need only get our feet wet to be able to progress. Those who want to take on faith that the Fourteenth Amendment protects activities that are essential to the family may wish to skip the substantive due process swamp altogether.

90. Bowers v. Hardwick, 478 U.S. 186, 191 (1986). 
In the next section, I will show how it is incoherent for anyoneradical, liberal, conservative, whatever - to deny that, as a factual matter, gay families may be plausibly considered families. Thus, putting theory and fact together, I conclude in the second section of this part that gay families fall within the zone of protection sketched out in Bowers itself, and note in the third section the consonance between this conclusion and the kinds of changes in historical fact envisioned in the Court's stare decisis jurisprudence. Finally, in the last part of the Essay, I will comment on what all of this might mean, and whether anyone should care about Bowers anyway.

\section{A. Remembering Substantive Due Process}

Everyone knows that no one knows what "substantive due process" really is. Judge Easterbrook believes it to be an oxymoron. ${ }^{91}$ John Hart Ely has called it a "contradiction in terms-sort of like 'green pastel redness.",'2 Its history, from contracts and social statics, through footnotes and penumbras, to its current association with contraceptives and abortions, is tangled, and at times, just plain bizarre. ${ }^{93}$ But then again, the doctrine, or something like it, has determined dozens of crucial, close cases before the Supreme Court. It clearly has some meaning, rooted in the idea that there are some liberties so foundational that no process can duly strip them from an American citizen-that there are some matters into which the state cannot intrude. Perhaps the textual foundation of this concept is obscure (or misplaced; perhaps it should be the Ninth Amendment, or the Privileges and Immunities Clause ${ }^{94}$ ), but the concept itself is not so arcane.

It is also becoming increasingly apparent that much of the debate about substantive due process is really a subset of a larger interpretative debate that dates back millennia: the debate between the letter and the spirit of the law. Are we to read the Constitution, with Justices Black and Scalia and others, according to the precise language of the text, in which case to infer rights from "penumbras" and notions

91. See Mays v. City of E. St. Louis, 123 F.3d 999, 1001 (7th Cir. 1997).

92. John Hart Ely, Democracy AND Distrust 18 (1980).

93. See generally Richard H. Fallon, Jr., Some Confusions About Due Process, Judicial Review, and Constitutional Remedies, 93 COLUM. L. REV. 309 (1993) (detailing the mysteries of due process); Toni M. Massaro, Reviving Hugo Black? The Court's "Jot for Jot" Account of Substantive Due Process, 73 N.Y.U. L. REV. 1086 (1998) (discussing the impact Graham v. Connor, 490 U.S. 386 (1989), has had on substantive due process).

94. See Ely, supra note 92, at 22-30, 34-41; LAUREnCE Tribe, AMERICAN CONSTITUTIONAL LAW $§ 15-3$ (2d ed. 1988). 
of fairness is a kind of hermeneutic fallacy, or worse, an invention of a do-gooder judge? Or are we to read the Constitution, with Justices Blackmun and Douglas and others, as implicitly mandating some basic form of fairness and justice, which we might see in the interests outlined in the Fourteenth Amendment? If we side with the latter Justices on the interpretive question, then we are likely to side with them on protecting a wider range of rights and interests. At the very least, we have to engage with the question of what a protected interest means, rather than question only whether an interest has been historically protected in the past. But more likely, trying to discern the spirit of the Constitution means trying to determine what "fundamental values" the document is really all about, and which, in a tiny minority of cases, will trump the expressed will of the Congress or a state legislature.

On the other hand, if we agree that the Constitution does not "implicitly mandate" anything, then substantive due process really is a bizarre stretch of the imagination. It would thus make sense to bury the doctrine entirely, or at least hamstring it by requiring that a fundamental right be a right that historically has been protected-i.e., by reducing it to a tautology. It might also make sense to resurrect a more appropriate textual source for substantive rights, most notably the Privileges and Immunities Clause, or to simply repeat, over and over again, that judges are not legislators; they are interpreters.

So what are we to do? The temptation is to count votes-to say, well, the textualists have three votes, the loose-constructionists have four or five, and then there's one or two in the middle. So substantive due process wins. Unless Bush wins the election, in which case it might lose. Maybe.

We do not have to remain in this cul-de-sac, however, because, in fact, substantive due process law has become relatively stable in the last decade. For this reason, I think we can for our purposes happily skirt the complex and tortured history of the Clause in trying to understand what it means today, as well as the larger hermeneutical issues of letter and spirit. In fact, though substantive due process is the doctrine that dare not speak its name-generally the phrase appears more often in Justice Scalia's dissents than in the Court opinions which actually apply the theory ${ }^{95}$-rumors of its death are greatly ex-

95. See, e.g., BMW of N. Am. v. Gore, 517 U.S. 559 (1996). The majority opinion, which found a due process protection from grossly excessive punitive damage awards, never uttered 
aggerated. Indeed, by looking at four or five recent cases, I think substantive due process begins to resemble an (almost) coherent doctrine. $^{96}$

Let us begin with Michael H. v. Gerald D., ${ }^{97}$ a plurality opinion written by Justice Scalia that contains the most restrictive definition of substantive due process announced by a sitting Justice. ${ }^{98}$ It is worth underscoring, emphasizing, and italicizing that the due process theory in Michael H. is not a majority opinion. First, Justice Scalia was writing only for a plurality of four-Justice Stevens concurred on separate grounds. Second, two of the four, Justices O'Connor and Kennedy, concurred in the opinion with the unusual exception of a single footnote, the note containing Justice Scalia's best statement of his constitutional method. We begin here only because it is the most minimal definition on the current judicial landscape.

Michael $H$. involved a child born to a married woman but not fathered by her husband. The biological father sought to be declared

the phrase "substantive due process." Justice Scalia's dissent uses variants of the term five times, scarequoted each time. See id. at 598-607 (Scalia, J., dissenting).

96. We will focus only on the doctrine as it applies to the family and related concerns, although it does have applicability in other areas as well. See id. at 562 (considering excessive punitive damages). See generally Michael J. Phillips, The Nonprivacy Applications of Substantive Due Process, 21 RUTGERS L.J. 537 (1990) (discussing various uses of substantive due process).

97. 491 U.S. 110 (1989) (Scalia, J., plurality opinion).

98. On Scalia's theory of substantive due process in Michael H., see Laurence H. Tribe \& Michael C. Dorf, Levels of Generality in the Definitions of Rights, 57 U. CHI. L. REV. 1057, 1058-59 (1990); Robin West, The Ideal of Liberty: A Comment on Michael H. v. Gerald D., 139 U. PA. L. REV. 1373, 1373-75 (1997). Justice Scalia may have taken an even more restrictive view of substantive due process in the very recent case of Troxel v. Granville. See $120 \mathrm{~S}$. Ct. 2054, 2074 (2000) (Scalia, J., dissenting). Dissenting from the Court's decision that a parent's substantive due process right to raise a child cannot be abrogated solely because a court believes it to be in the best interests of the child, Justice Scalia strongly suggested that no unenumerated right can be protected by the courts, despite several precedents protecting a parent's right to raise a child as the parent wishes. See id. at 2074 (Scalia, J., dissenting) ("I do not believe that the power which the Constitution confers upon me as a judge entitles me to deny legal effect to laws that (in my view) infringe upon what is (in my view) [an] unenumerated right."). Because Justice Scalia's Troxel dissent does not discuss the parameters of right-drawing, it is extrinsic to our discussion here. It strongly suggests, however, that such discussions may now be irrelevant to Justice Scalia. His dissent, however, was joined by no other Justice; even Justice Thomas, writing separately, would have found a substantive due process interest at issue. See id. at 2068 (Thomas, J., concurring) (asserting that "parents have a fundamental constitutional right to rear their children" and noting that he "would apply strict scrutiny to infringements of fundamental rights"). Though Justice Thomas did not reach the substantive due process question, the plurality certainly did. See id. at 2059-60 (listing over a dozen precedents and stating that "it cannot now be doubted that the Due Process Clause of the Fourteenth Amendment protects the fundamental right of parents to make decisions concerning the care, custody, and control of their children"). 
the father of the baby, but was barred from doing so by a California statute that presumes the husband to be the father of any child born into wedlock. The Court upheld the statute against a substantive due process challenge by the biological father. Writing for the plurality, Justice Scalia noted that "[i]t is an established part of our constitutional jurisprudence that the term 'liberty' in the Due Process Clause extends beyond freedom from physical restraint." for restraint in interpreting the Clause, Justice Scalia held that it only applies to "an interest traditionally protected by our society." ${ }^{100}$ Furthering his case, Justice Scalia quoted Justice Cardozo's influential opinion in Snyder v. Massachusetts, ${ }^{101}$ which held that certain rights "so rooted in the traditions and conscience of our people as to be ranked as fundamental" Process Clause. ${ }^{103}$ And yet, like Justice White's glossing over of the "concept of ordered liberty," 104 Justice Scalia never mentioned "conscience" again. The rest of his exposition of Due Process Clause jurisprudence focused only on "history and tradition," 105 concluding that "the legal issue ... reduces to whether the relationship [at issue] has been treated as a protected family unit under the historic practices of our society, or whether on any other basis it has been accorded special protection." 106

Further, in footnote 6, Justice Scalia-now writing only for himself and the Chief Justice-defended the use of "historical traditions specifically relating to the rights of an adulterous natural father," as opposed to those regarding "parenthood," or some more general value. ${ }^{107} \mathrm{He}$ analogized Michael $H$. to Bowers and Roe v. Wade, ${ }^{108}$ each of which traced the history of laws about sodomy and abortion, as opposed to, say, sexual relations or pregnancy more generally. The specific approach, Justice Scalia wrote, is the only approach, because

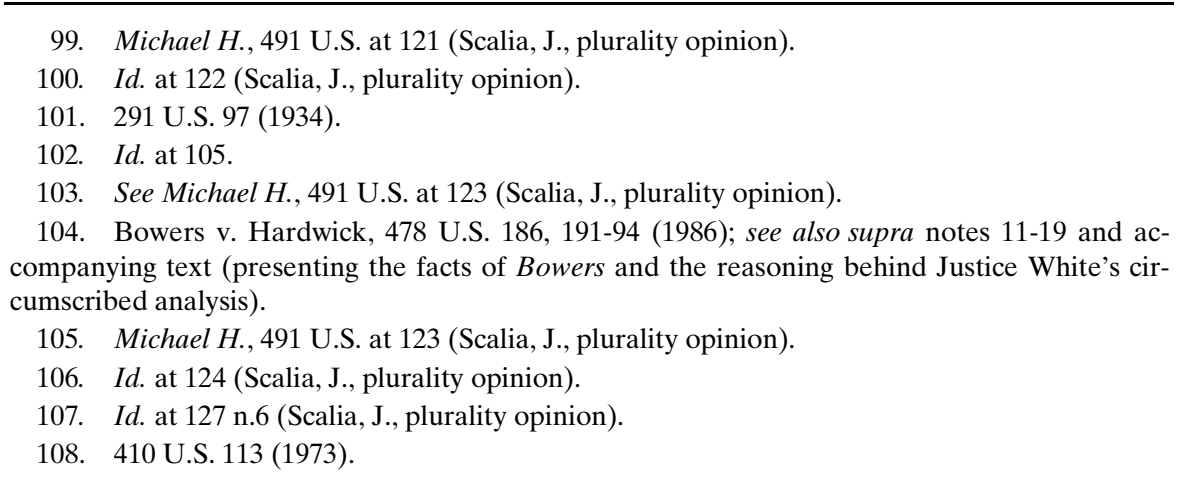


no other criterion is available for demarcating the boundaries of the Court's inquiry. ${ }^{109}$

Not surprisingly, Justice Scalia's approach met with some criticism, beginning with Justice Brennan's dissent in Michael H. itself. First, Justice Brennan wrote, the concept of tradition "can be as malleable and as elusive as 'liberty' itself,"110 arguing that Justice Scalia had been overly selective with his use of precedent and history. Second, Justice Brennan accused Justice Scalia's method of being circular: a right only exists if it is traditionally recognized and protected, but if the right has been protected, why has the lawsuit been brought ${ }^{111}$ One must look beyond the immediate circumstances to the general interest affected, Justice Brennan wrote, in order to see what fundamental rights are at issue. ${ }^{112}$ After all, fundamental rights are just that: fundamentals. Finally, Justice Brennan resorted to Scalia-like barbs - calling the Scalia Constitution "a stagnant, archaic, hidebound document steeped in the prejudices and superstitions of a time long past." 113

Even without such characterizations, Justice Scalia's restrictive method does seem circular: a right is protected if it is protected, not protected if it isn't. ${ }^{114}$ If constitutional adjudication is ever to transcend just affirming the traditional (think again of Loving v. Virginia), there must be more. And yet, as Cass Sunstein asked in 1997, "[i]f tradition is not decisive, what is the source of fundamental rights for purposes of substantive due process? This is one of the largest unanswered questions in American jurisprudence, and it would be foolish to attempt a full answer here." 115 As Sunstein did in his essay, however, it is possible to discover what sorts of acts have been protected by the Court, and how they hang together in some semblance of a co-

\footnotetext{
109. See Michael H., 491 U.S. at 127 n.6 (Scalia, J., plurality opinion).

110. Id. at 137 (Brennan, J., dissenting).

111. See id. at 138-39 (Brennan, J., dissenting).

112. See id. at 139-40 (Brennan, J., dissenting).

113. Id. at 141 (Brennan, J., dissenting). But see West, supra note 98, at 1374-81 (suggesting similarities between Justice Brennan's and Justice Scalia's theories of substantive due process as revealed in Michael $H$.).

114. See Michael H., 491 U.S. at 139 (Brennan, J., dissenting) (noting that Justice Scalia's approach cannot explain a long list of cases including Vitek v. Jones, 445 U.S. 480 (1980) (barring the "arbitrary transfer from a prison to a psychiatric institution"); Ingraham v. Wright, 430 U.S. 651 (1977) (barring some forms of corporal punishment in schools); and Roe v. Wade, 410 U.S. 113 (1973) (announcing that pregnant women have a constitutional right to an abortion)).

115. Cass Sunstein, The Right to Die, 106 Y ALE L.J. 1123, 1136 (1997).
} 
herent theory. This may be insufficient theory, but for our practical purposes, it is adequate doctrine.

Consider, for example, Planned Parenthood v. Casey, ${ }^{116}$ which, though perhaps more famous/notorious for its discussion of stare decisis, contains the Supreme Court's most articulate recent iteration of substantive due process law as applied to the area of family relations. In Casey, the Court ${ }^{117}$ first reiterated the foundations of substantive due process law, in Souterian detail, from Justice Brandeis's concurrence in Whitney v. California ${ }^{118}$ to the present. ${ }^{119}$ The Casey Court also explicitly rejected Justice Scalia's footnote in Michael H., citing Loving and several other cases. ${ }^{120} \mathrm{Next}$, reciting the holdings in Eisenstadt v. Baird, ${ }^{121}$ Roe v. Wade, ${ }^{122}$ Griswold v. Connecticut, ${ }^{123}$ Moore v. East Cleveland, ${ }^{124}$ and other cases, the Court in Casey stated that to ascertain what "liberty" is requires "reasoned judgment" of the place

116. 505 U.S. 833 (1992).

117. Casey is a difficult opinion to parse because it is never clear who is speaking for whom at what point in which opinion. However, the discussion of substantive due process related herein occurs in Part II of the plurality opinion, which was titled "Opinion of the Court" and which was joined by Justice Stevens and Justice Blackmun.

118. Justice Brandeis wrote:

Despite arguments to the contrary which had seemed to me persuasive, it is settled that the due process clause of the Fourteenth Amendment applies to matters of substantive law as well as to matters of procedure. Thus all fundamental rights comprised within the term liberty are protected by the Federal Constitution from invasion by the States.

Whitney v. California, 274 U.S. 357, 373 (1927) (Brandeis, J., concurring), quoted in Casey, 505 U.S. at $846-47$.

119. See Casey, 505 U.S. at 846-51.

120. Referring to Justice Scalia's plurality opinion in Michael H., the Court wrote:

It is tempting, as a means of curbing the discretion of federal judges .... to suppose that the Due Process Clause protects only those practices, defined at the most specific level, that were protected against government interference by other rules of law when the Fourteenth Amendment was ratified. But such a view would be inconsistent with our law. It is a promise of the Constitution that there is a realm of personal liberty which the government may not enter. We have vindicated this principle before. Marriage is mentioned nowhere in the Bill of Rights and interracial marriage was illegal in most States in the 19th century, but the Court was no doubt correct in finding it to be an aspect of liberty protected against state interference by the substantive component of the Due Process Clause in Loving v. Virginia (relying, in an opinion for eight Justices, on the Due Process Clause).

Id. at 847-48 (citations omitted).

The Court also cited, for the same proposition, Turner v. Safley, 482 U.S. 78, 94-99 (1987), Carey v. Population Servs. Int'l, 431 U.S. 678, 684-86 (1977), Griswold v. Connecticut, 381 U.S. 479, 481-82 (1965), and other cases. See Casey, 505 U.S. at 847-48.

121. 405 U.S. 438 (1972).

122. 410 U.S. $113(1973)$.

123. 381 U.S. $479(1965)$.

124. 431 U.S. 494 (1977). 
of a given act within the "rational continuum" of the concept of liberty. ${ }^{125}$ Of most interest to us here is the statement that

[o]ur law affords constitutional protection to personal decisions relating to marriage, procreation, contraception, family relationships, child rearing, and education.... These matters, involving the most intimate and personal choices a person may make in a lifetime, choices central to personal dignity and autonomy, are central to the liberty protected by the Fourteenth Amendment. ${ }^{126}$

The Casey dissent, written by Chief Justice Rehnquist, takes a similar view, though it distinguishes the abortion decision from "marriage, procreation, and contraception" because abortion "involves the purposeful termination of a potential life."127 Indeed, by the time Glucksberg is decided in 1997-and Justice Souter's encyclopedic concurrence in that case is written ${ }^{128}$-all members of the Court agree that personal decisions relating to "family relationships" are protected, differing only on how narrowly or broadly to construe the right, and whether some particular decisions (like abortion) are properly within the nest of family choices. As the Court said in 1974, "freedom of personal choice in matters of ... family life is one of the liberties protected by the Due Process Clause of the Fourteenth Amendment." ${ }^{129}$ A quarter century later, this core principle has remained, despite the doctrinal debate and confusion; if there is a "connection" between a given act and "marriage, procreation, contraception, or family relationships," there must be a compelling state interest in order to justify intervention.

125. Casey, 505 U.S. at 848-49 (quoting Poe v. Ullman, 367 U.S. 497, 543 (1961) (Harlan, J., dissenting)).

126. Id. at 851; accord Bowers v. Hardwick, 478 U.S. 186, 191 (1986) (protecting actions with a "connection" to family, marriage, or procreation).

127. Casey, 505 U.S. at 952 (Rehnquist, C.J., dissenting) (quoting Harris v. McRae, 448 U.S. 297, 325 (1980)). But see Washington v. Glucksberg, 521 U.S. 702, 726-27 (1997) (stating that "'the right to define one's own concept of existence, of meaning, of the universe, and of the mystery of human life" " was a description of activities, not a prescription for rights protection) (quoting Casey, 505 U.S. at 851).

128. See Glucksberg, 521 U.S. at 755-65 (Souter, J., concurring).

129. Cleveland Bd. of Educ. v. LaFleur, 414 U.S. 632, 639-40 (1974). 


\section{B. Applying Substantive Due Process to Bowers II: Defining the Family, the Kulturkampf, and "Live and Let Live"}

In the name of family values, we must ask whose family ... Senator?

$$
\text { Lou Reed, } 1996^{130}
$$

Thus, if gay relationships have some connection to "family relationships," they and their constitutive activities (including, presumably, sex) are protected by the Fourteenth Amendment. Now, as Justice Stevens said while concurring in Michael H., "enduring 'family' relationships may develop in unconventional settings." tutional $\$ 64,000$ question is whether they may develop in the context of family-like gay relationships.

As a threshold matter, the question of how narrowly or widely to view the right alleged is barely present here: we agree it is "gay sodomy," not "sexual relations" generally. The argument will be that gay families fall within the already-protected box of the family, and that sodomy is a part of gay families, just as decisions about sex and procreation are part of families in general. I intend fully to stay within Bowers, which itself required some "connection" between the alleged right and the family. Thus the knotty question of how to characterize a particular right does not enter here.

We should begin with three Supreme Court cases - two old, one quite new-that address the meaning of the term "family." 132 Not one

130. Lou ReEd, Sex With Your Parents (Motherfucker) Part II, on SET THE TwiLIGHT REELING (Warner Bros. 1996).

131. Michael H. v. Gerald D., 491 U.S. 110, 133 (1989) (Stevens, J., concurring).

132. In addition to the three cases discussed here, the Supreme Court grappled with the definition of "family" in Smith v. Organization of Foster Families for Equality and Reform, 431 U.S. 816 (1977), which involved procedures for removing foster children from their temporary foster parents. Writing for the Court, Justice Brennan recognized that "biological relationships are not exclusive determination [sic] of the existence of a family," $i d$. at 843 , instead stating that

the importance of the familial relationship, to the individuals involved and to the society, stems from the emotional attachments that derive from the intimacy of daily association, and from the role it plays in "promot[ing] a way of life" through the instruction of children as well as from the fact of blood relationship.

Id. at 844 (quoting Wisconsin v. Yoder, 406 U.S. 205, 231-33 (1972)). But Justice Brennan questioned whether a temporary foster relationship, a creation of the state, was entitled to the same protection as families, because "the liberty interest in family privacy has its source, and its contours are ordinarily to be sought, not in state law, but in intrinsic human rights, as they have been understood in 'this Nation's history and tradition."' Id. at 845 (quoting Moore v. East Cleveland, 413 U.S. 494, 503 (1977)). The question was left unanswered because even assuming a liberty interest existed, the Court concluded that the removal procedures in question did not violate procedural due process. See id. at 847 . 
is conclusive. On the one hand, in Village of Belle Terre v. Boraas, ${ }^{133}$ the Court upheld a zoning ordinance based on a very wide definition of "family" - one which, in fact, would include gay families-against a challenge by a group of six unrelated students who still did not fall within its ambit. ${ }^{134}$ Though the students argued "that if two unmarried people can constitute a 'family' there is no reason why three or four may not," ${ }^{135}$ the Court disagreed, observing that "every line drawn by a legislature leaves some out that might well have been included. That exercise of discretion, however, is a legislative, not a judicial, function." ${ }^{136}$ But the Court never engaged with the question of whether the city could really define a "family" for constitutional purposes, or even take seriously the students' claims that they were a family. It seemed obvious that they were not; the students moved in separately, as co-lessees of one village resident. ${ }^{137}$ Obviously, this is clearly distinguishable from a case in which two lifelong partners seek to pursue something that closely resembles a family life; therefore, Belle Terre does not control.

On the other hand, consider Moore v. East Cleveland, ${ }^{138}$ decided just two years after Belle Terre. In Moore, the Court struck down a zoning ordinance that had the effect of barring a grandmother from living with one of her grandsons. The distinction between Moore and Belle Terre, the Court said, was that "[t]he ordinance [in Belle Terre] affected only unrelated individuals.... East Cleveland, in contrast, has chosen to regulate the occupancy of its housing by slicing deeply into the family itself." 139 Thus, the statute implicated a fundamental right and failed strict scrutiny. Here, the Court did engage with the city's argument that the grandmother-grandson relation was not a

\footnotetext{
133. 416 U.S. 1 (1974).

134. The definition of "family" at issue in Belle Terre was

[o]ne or more persons related by blood, adoption or marriage, living and cooking together as a single housekeeping unit, exclusive of household servants. A number of persons but not exceeding two (2) living and cooking together as a single housekeeping unit though not related by blood, adoption, or marriage shall be deemed to constitute a family.

Id. at 2 .

135. Id. at 8 .

136. Id.

137. See id. at 2-3. Only Justice Marshall found the students' freedom of association and "right to "establish a home"" to be infringed by the zoning ordinance. Id. at 15 (Marshall, J., dissenting).

138. 431 U.S. 494 (1976).

139. Id. at 498 .
} 
"family" for constitutional purposes. ${ }^{140}$ While agreeing that it had not extended constitutional protection beyond the nuclear family, the Court went on to quote the Harlan dissent in Poe v. Ullman, ${ }^{141}$ and held that "[o]urs is by no means a tradition limited to respect for the bonds uniting the members of the nuclear family. The tradition of uncles, aunts, cousins, and especially grandparents sharing a household along with parents and children has roots equally venerable and equally deserving of constitutional recognition." ${ }^{142}$ Of course, this emphasis on "tradition," and the list of relatives is precisely what makes Moore of little use to a reconsideration of Bowers - call it Bowers IIdespite its promising beginning. Moore does suggest that non-nuclear families with traditions in American culture are protected by the Fourteenth Amendment, but says nothing about non-nuclear families with only recently evolved traditions in American culture.

Still, Moore does make one critical point: that the definition of "family" is something that itself can abridge fundamental rights, and that, as a consequence, a legislature cannot choose a definition; the Constitution protects not only "family matters" but also what grouping can legitimately be called a "family." if we think about it carefully. Yes, to quote Casey, "[i]t is conventional constitutional doctrine that where reasonable people disagree the government can adopt one position or the other." ${ }^{, 144}$ But not when a fundamental right is abridged. Casey went on to say that "[t]hat theorem, however, assumes a state of affairs in which the choice does not intrude upon a protected liberty." 145 In other words, if having a gay family is a protected right, then the state cannot define it away by saying that a gay family is not a "family." An analogy: a state may not

140. East Cleveland argued that the Fourteenth Amendment protections extended only "to the nuclear family — essentially a couple and their dependent children." Id. at 500.

141. 367 U.S. 497 (1961). The Court quoted the following language: "Here we wave not an intrusion into the home so much as on the life which characteristically has its place in the home... The home drives its pre-eminence as the seat of family life." Id. at 551-52 (Harlan, J., dissenting), quoted in Moore, 431 U.S. at 503 n.12.

142. Moore, 431 U.S. at 504.

143. Interestingly, the inquiry is not dissimilar from that of abortion rights; the question in both contexts concerns the parameters of constitutional categories. No pro-choice advocates that I know of support "the killing of human life" or a constitutional right thereto. Their point is that beliefs about "one's own concept of existence, of meaning, of the universe, and of the mystery of human life," Planned Parenthood v. Casey, 505 U.S. 833, 851 (1992), are themselves "intimate and personal choices" protected by the Fourteenth Amendment.

144. Id. at 851.

145. Id. 
ban the burning of a flag, even if an overwhelming majority of the state's citizens see it as an odious act, by declaring that "flag burning is not political speech" and that it therefore may be abridged. Whether flag burning is political speech or not is a constitutional question, and therefore it is not up to the legislature to decide. Likewise, if there is a fundamental right at issue, a state cannot just declare it away by stating that "the gay family is not a family." To allow the abrogation of a possible right by defining it out of existence is not to protect that right.

Finally, our analysis must take note of a third, quite recent case: Troxel v. Granville, ${ }^{146}$ which the Supreme Court decided on June 5, 2000. At issue in Troxel was a Washington statute which allowed "any person" to petition for visitation rights to a child, and to prevail if a court found such visitation to serve the best interest of the child. ${ }^{147}$ The petitioners in Troxel were the grandparents of a child, whose father (the petitioners' son) had died, a fact pattern that led some observers to speculate that the Court might articulate what family-based right grandparents possess regarding the rearing of a grandchild. This was not the Court's choice, however. Finding that the Washington statute was "breathtakingly broad," two issues. First, the Court considered a parent's substantive due process right to raise a child free of state interference. Second, the Court addressed the question of how, in the instant case, such rights were abrogated on the basis of what the Court called a "mere disagreement" over the best interests of the child, rather than respecting the mother's constitutionally protected determination of the child's best interests. ${ }^{149}$ Thus Troxel ended up being less about extended family rights than about the constitutionally-derived "traditional presumption that a fit parent will act in the best interest of his or her child."

Perhaps in response to active briefing by various legal interest groups, however, the Court did go out of its way to note at the outset of its reasoning that " $[\mathrm{t}]$ he demographic changes of the past century

\footnotetext{
146. 120 S. Ct. 2054 (2000).

147. Id. at 2057-58.

148. Id. at 2056.

149. Id. at 2061-63.

150. Id. at 2062. Justice Stevens' fascinating and carefully worded dissent argues that the Court must take account not only of the mother's Fourteenth Amendment rights but also of those of the child, who, Justice Stevens wrote, may have "liberty interests in preserving established familial or family-like bonds." Id. at 2072 (Stevens, J., dissenting). No other Justice adopted this approach, however.
} 
make it difficult to speak of an average American family" and that "[t]he composition of families varies greatly from household to household." ${ }^{151}$ Justice O'Connor, writing for the Court, acknowledged that " $\mathrm{t}]$ he nationwide enactment of nonparental visitation statutes is assuredly due, in some part, to the States' recognition of these changing realities of the American family," ${ }^{152}$ although ultimately the Court held that such statutes must respect the constitutional rights of a parent to determine the best interests of the child (absent, of course, a finding that the parent is unfit). Moreover, the Court based Troxel's holding that "the Due Process Clause does not permit a State to infringe on the fundamental right of parents to make childrearing decisions simply because a state judge believes a 'better' decision could be made" ${ }^{153}$ on the facts of the case before it; it never had to reach the question of what rights grandparents might possess, because such rights were not alleged by the trial court. ${ }^{154}$ To reach its conclusion, Troxel provided dicta on the subject of the changing family, but had no need to act on its consequences.

So, if the legislature cannot define a right away (Moore), tradition does not provide adequate protection (Loving), and families are changing every day (Troxel), but implausible aggregations of people are clearly not families (Belle Terre), then it seems the Court must decide whether a potential family unit is, legally speaking, a "family." We're back, then, to the questions asked above: how does it decide? With neither strict tradition nor legislative guidance, should the Court take a poll? Read the Bible? Ought it look at history and sociology, both of which tell us that the modern nuclear family is a very recent phenomenon, and only one of many Western ideals of family? ${ }^{155}$ Or ought the Court use what philosophers of language and commonsense alike tell us is the source of the meaning of words: how they are used in society?

\footnotetext{
151. Id. at 2059 .

152. Id.

153. Id. at 2064 .

154. See id. at 2063. The trial court based its decision on the findings that the Troxels "are part of a large, central, loving family ... [and] can provide opportunities for the children in the areas of cousins and music" and that "[t]he children would be benefited from spending quality time with the [Troxels]." Id.

155. See Craig W. Christensen, If Not Marriage? On Securing Gay and Lesbian Family Values by a "Simulacrum of Marriage", 66 FORDHAM L. REV. 1699, 1713-16 (1998) (surveying studies on the evolution of the nuclear family).
} 
The trouble with answering these questions is that the answers seem ineluctably political. It seems as though if one is morally or politically for "gay rights," then, for you, it is obvious that a "family" includes gay couples - a fortiori if one is gay, and involved in a longterm family relationship, in which case even the question is somewhat offensive. So tradition is less important, culture and social practice more. On the other hand, if you are against "gay rights," then you would likely invoke "traditional" notions of the family (however fictional they may be ${ }^{156}$ ) deliberately to resist their erosion. The political ends can easily determine the methodological means.

We can recast the question as one of relativism versus absolutism, itself a political polarity. On the extreme relativist end of the spectrum is to say that anything someone wants to call a "family" is a family: a single woman and her fish tank, a child and her dollhouse, maybe even a organization of Mafiosi. Presumably, few of us would agree that these "families" are entitled to constitutional protection, however. Even if we have little interest in arguing with any of these "families" (particularly the Mafiosi), the use of "family" in this way empties the term of communitarian meaning, and renders it merely a tool for ordering legal norms. More seriously, definitions of "family" that depend only on "love" or "support," without more, may resonate with the experience of families that differ in structure from the stereotypical nuclear family -in the glib phrasing of Libby Post, "mother, father, a couple of children and a pet" $" 157$ - but, for legal or constitutional purposes, they do not get us very far. ${ }^{158}$ Are fundamental rights pertaining to the family to be extended to every conglomeration of individuals (including pets) where the bonds of love and affection exist? And even if they are, who is to adjudicate love? And why love as opposed to tribe, or kinship, or procreation? Expansive definitions of

156. On the rhetorical value of the family fiction, see generally STEPHANIE COONTZ, THE WAY WE NEVER WERE (1992).

157. Libby Post, The Question Of Family: Lesbians and Gay Men Reflecting A Redefined Society, 19 FordHAM URB. L.J. 747, 748 (1992).

158. For such wider definitions of the family, see, for example, Barbara J. Cox, Love Makes a Family —Nothing More, Nothing Less: How the Judicial System Has Refused to Protect Nonlegal Parents in Alternative Families, 8 J.L. \& POL. 5, 5 n.1 (1991); Mary Patricia Treuthart, Adopting a More Realistic Definition of "Family", 26 GonZ. L. REV. 91, 91 (1990/1991). As will become clear, ingredients like love and support are important to my own sociologically-derived agnosticism regarding what a family "is," because they are constitutive elements of many (though not all) families in America today. But my (non-)definition does not depend on these elements alone; it also requires actual social practice and acceptance by at least some parts of American society. 
the "family," however they may capture the personal meaning of "family" for many people, render the term nearly empty of legal usefulness. We are all Humpty-Dumpty ("When $I$ use a word ... it means just what I choose it to mean - neither more nor less." ${ }^{159}$ ) and common meaning is impossible. Since adjudication depends on common meaning of the terms to be adjudicated, the extreme relativist position fails as a workable norm for deciding legal cases. ${ }^{160}$

The other extreme position is to be as selectively, minimalistically historical as possible: a family is only that which has historically been recognized as such-a man, a woman, a marriage contract, with children optional. If the relativist position excelled in flexibility but lacked clarity, the minimalist position is the exact opposite: it is easy to know exactly what is and is not a family-although prior to the postwar "nuclear family," an innovation combining the contingencies of the period with romanticized myth, ${ }^{161}$ many family arrangements commonplace in America would strike us as hardly being families at all; children farmed out to work far from home, extended families of slaves, marriages in which cohabitation was infrequent at best, and so on. But even if we set actual historical practice aside in favor of "tradition," we are back at the Loving problem: what about when the traditional definition of "family" itself runs afoul of constitutional norms? That is, to define the family only in terms of one view of tradition (since one can find multiple conflicting traditions, depending on where one looks) may replicate the problem of improperly defining a right out of existence by choosing a definition that is so narrow as to remove from consideration "real" families that may demand constitutional protection. This problem is particularly acute today. Although recent polls show up to $90 \%$ of respondents favoring "oldfashioned ideas about family and marriage," 162 the fact is that "traditional nuclear families" are only a small minority-less than $25 \%$ of American households - and alternative families are becoming more and more common. ${ }^{163}$ The Court in Troxel noted that as of 1996, chil-

\footnotetext{
159. LeWIS CARroll, Through the LoOKING Glass 69 (1931).

160. The extreme relativist position would also fail if we wished to avoid the slippery-slope of incestuous families and the like, although I think that particular slippery-slope is rather overused.

161. See CoONTZ, supra note 156, at 25-29 (highlighting the novelty of the 1950s family).

162. Craig W. Christensen, Legal Ordering of Family Values: The Case of Gay and Lesbian Families, 18 CARDOZO L. REV. 1299, 1310 (1997).

163. See id. at 1310-11 (citing census statistics and CoONTZ, supra note 156, at 21); Martha Farnsworth Riche, The Future of the Family, AM. DEMOGRAPHICS, Mar. 1991, at 44 (docu-
} 
dren living with only one parent accounted for $28 \%$ of all children under age eighteen in the United States. ${ }^{164}$ Even more importantly for gay families, unmarried, cohabiting couples, for instance, are growing in number-as of 1993, there were 5 million such couples in America-about 1.5 million of which consist of same-sex "partners." ${ }^{, 165}$ In such a changing social context, the risk of underinclusion is large indeed.

One might take a modified-minimalist approach to defining the family: a "family" is a traditional family except where tradition clearly violates a constitutional norm, such as equal protection. That's fine as far as it goes-it gets around the Loving problem, for example, by excluding the anti-miscegenation definition of family/marriage because of its transgression of equal protection. But, again, the trouble is that sometimes whether a constitutional norm exists depends on whether there is a family - the instant case, for example. In such cases, to use the modified-Scalia definition of "family" is circular: a constitutional norm depends on whether there is a family, but whether a nontraditional family is a "family" or not depends on whether there is a constitutional norm implicated. In other words, gay families are families if to deny them the status of "family" would violate a constitutional right of gays-but the only way to know whether there is a constitutional right in play or not is to determine whether gay families are families! So much for modified-Scalia.

What, then? One somewhat nihilistic alternative is to just look it up, a method that would surely make Aristotle wince but which does seem to crop up in a surprising number of judicial opinions. The prospects are grim. Webster's Third International Dictionary gives us two-thirds of a column on the word "family." But even if we exclude the irrelevant definitions (e.g., related chemical compounds), what's left is of little use. Is a family "a group of persons of common ancestry"? "[A] male and female animal with their young"? That doesn't seem to include enough. "[A] group of individuals living under one roof"? That seems to include both too much and too little. Here's a better one: "the body of persons who live in one house and under one head including parents, children, servants, and lodgers or boarders."

menting changes in American households); see also Martha Minow, The Free Exercise of Families, 1991 U. ILL. L. REV. 925, 930-32 (describing the modern transformation of the 1950s family).

164. See Troxel v. Granville, 120 S. Ct. 2054, 2059 (2000) (citing a 1998 census report).

165. See Christensen, supra note 162, at 1312-14 (citing census statistics). 
But that seems too expansive for constitutional purposes. So does "a group of persons sharing a common dwelling and table considered for census purposes to include at one extreme a single person living alone and at the other the residents of a hotel or the inmates of a prison., ${ }^{166}$ The best definition Webster's gives is "the basic biosocial unit in society having as its nucleus two or more adults living together and cooperating in the care and rearing of their own or adopted children."167 Seems to get it right for straight and gay families (except I'm not sure that children are essential) but, really, is this what constitutional interpretation is about? Webster's?

Maybe, then, we should look more deeply into the concept of the American nuclear family and inquire what its functions and structures are-what are, in the words of one New York court, "normal familial characteristics." 168 Here, too, however, there is bound to be dispute. For Craig Christensen, nuclear families involve "compassionate cohabitation," 169 the rearing of children, and some degree of autonomy. ${ }^{170}$ Very well; gay families can involve these things. But one could still respond that "family" also necessarily includes the transmission of communal values-which might include religious, heterosexist values-or biologically producing children. How to arbitrate this dispute? Once again, without evidence, conceptual and functional definitions are a matter of opinion.

Likewise, public opinion polls are, by definition, measures of "opinion" rather than constitutional definition or actual societal practice, although it is worth at least parenthetically noting that, as early as 1989, nearly three-quarters of those polled selected "a group of people who love and care for one another" as a definition of the

\footnotetext{
166. In fact, the census definition is more restrictive: "A family group is any two or more persons ... residing together, and related by birth, marriage, or adoption." BUREAU OF THE Census, U.S. Dep'T of Commerce, Current Population Reports, SERIEs P-20, No. 484, MARITAL StATUS AND LiVING ARRANGEMENTS: MARCH 1994, at B-1 (1996). Of course, this definition is entitled to no more deference than any other, since if it is unconstitutional, it is of no moment that an executive agency has adopted it.

167. This and all the preceding definitions are from Webster's THIRD NEW INTERNATIONAL DICTIONARY 821 (1993).

168. Braschi v. Stahl Assocs. Co., 543 N.E.2d 49, 54 (N.Y. 1989).

169. Christensen, supra note 155, at 1716 (quoting JAN E. DiZARD \& Howard GadLin, THE Minimal FAMiLy 139-42 (1990)).

170. See id. at 1716-18.
} 
"family," over "a group of people related by blood, marriage, or adoption.",

We need evidence, not declarations, and I think we have to return to society for that evidence, for three reasons. First, because for a term that is as unstable and contentious as "family," it's hard to see where else to turn; competing conceptual definitions may be equally valid, and the choice between them seems inexorably political. Second, the family unit is a social unit; it has import not only for the individual members of an individual family but for the culture in which that family interacts. In the words of the California Supreme Court,

[t]he family is the basic unit of our society, the center of the personal affections that ennoble and enrich human life. It channels biological drives that might otherwise become socially destructive; it ensures the care and education of children in a stable environment; it establishes continuity from one generation to another; it nurtures and develops the individual initiative that distinguishes a free people. ${ }^{172}$

Some of these functions of the family are individually oriented, others socially oriented; thus, both aspects of the family-individual love, support, etc., and social function, role, and acceptance-may be essential. ${ }^{173}$ Third, taking a cue from both Wittgenstein and common sense, social usage is where terms acquire their meaning; words mean what they mean in usage and communication, not in an idiosyncratic (and probably impossible) private imagination. Humpty-Dumpty has it wrong because to use a word in a way no one can understand is not to "use" a word in the conventional sense; it is to misuse it.

So, given the multiplicity of family structures in American social practice, what is the evidence as it pertains to gay "families"? In the fourteen years since Bowers was decided, the kulturkampf over gay

171. Treuthart, supra note 158, at 97 (citing Jean Seligmann, Variations on a Theme, NEWSWEEK, Special Edition, Winter/Spring 1990, at 38).

172. De Burgh v. De Burgh, 250 P.2d 598, 601 (Cal. 1952).

173. For Laurence Tribe, the protection of family is not a random outgrowth of Fourteenth Amendment jurisprudence but is the result of the structure of American society itself: "' $[\mathrm{T}] \mathrm{he}$ family unit does not simply co-exist with our constitutional system,' but 'is an integral part of it,' for our 'political system is superimposed on and presupposes a social system of family units, not just of isolated individuals. No assumption more deeply underlies our society ...." LAURENCE H. Tribe, American Constitutional LAW § 15.19, at 1414 (2d ed. 1988) (quoting Philip B. Heymann \& Douglas E. Barzelay, The Forest and the Trees: Roe v. Wade and its Critics, 53 B.U. L. REV. 765, 772-73 (1973)); see also Case, supra note 13, at 1655-56 (suggesting that the failure of various gay rights cases is attributable to the inability of judges to view gay relationships in terms of long-term "couples" rather than short-term sexual behaviors). 
rights has come a long way. The corporate world has, in the last decade, accorded greater recognition to gay family units than ever before; according to a Human Rights Campaign report, at least 2,856 private and public employers offered domestic partner health coverage as of August 1999-compared with about two dozen in $1990 .^{174}$ Among those were seventy Fortune 500 companies, including IBM, AT\&T, Disney, Chevron, and General Mills, all of whom added their policies in the last seven years. ${ }^{175}$ Seventy-three local governments or government agencies offer domestic partner health insurance, including six states, ${ }^{176}$ and several localities add domestic partner registries every year. ${ }^{177}$

In addition, though faced with many obstacles, gays and lesbians are able to adopt children and become guardians for each other in case of illness. ${ }^{178}$ The Constitution of Vermont has been read to require the recognition of gay couples as, if not married, then the functional equivalent of married. ${ }^{179}$ Many courts have taken a functionalist view of the family and recognized same-sex partners as family members-the New York Court of Appeals, for example, prohibited the eviction of a gay man from a rent-controlled apartment following his partner's death, holding that he qualified as a surviving family member because the couple were "two adult lifetime partners whose relationship is long term and characterized by an emotional and financial commitment and interdependence." 180 Though treatment among state

174. See Human Rights Campaign, The State of the WorkPlace 19-20 (1999) [hereinafter HRC Report]. A 1997 KPMG Peat Marwick study reported that $13 \%$ of American corporations offer such benefits. See id. at 19.

175. See id. at 33-34.

176. See id. at 15.

177. See id. at 17 (localities creating such registries in 1998 and 1999 included Broward County, Florida, and Milwaukee, Wisconsin); see also Treuthart, supra note 158, at 100-05 (detailing typical registration procedures and citing registries established in Seattle, Washington, and in the California cities of West Hollywood, Santa Cruz, and Berkeley).

178. See Christensen, supra note 162, at 1301, 1406-14 (demonstrating that cases from various jurisdictions have either explicitly or implicitly upheld the legality of gays and lesbians adopting children).

179. See Baker v. State, 744 A.2d 864, 886-88 (Vt. 1999).

180. Braschi v. Stahl Assocs., 543 N.E.2d 49, 54 (N.Y. 1989); see also Donovan v. Workers' Compensation Appeals Bd., 187 Cal. Rptr. 869, 873 (Cal. Ct. App. 1982) (allowing one gay partner to receive benefits if he could demonstrate dependence on his deceased partner). But see, e.g., Coon v. Joseph, 237 Cal. Rptr. 873, 876-78 (Cal. Ct. App. 1987) (holding that a gay man did not have a sufficiently close relationship with his life partner to recover in tort for emotional distress after witnessing an assault); Weigand v. Houghton, 730 So. 2d 581, 585-88 (Miss. 1999) (denying custody of a child to a wealthy, gay father, despite evidence of abuse from an economically disadvantaged, straight stepfather). 
courts is very uneven, ${ }^{181}$ it at least makes sense to discuss gay and lesbian family law as a coherent subject, unlike in $1986 .{ }^{182}$ Changes in social attitudes have already yielded important gains in gay civil rights generally, from employment contexts to school groups, ${ }^{183}$ and they matter constitutionally as well.

Even apart from judicial recognition, gay family groupings exist and are visible in American culture now as never before. Gay men and women are on television and in movies, portrayed as parts of families, in a way unthinkable in 1986. There are American Express ads targeting lesbian couples, ${ }^{184}$ Budweiser ads with men holding hands (and I don't mean high-fiving), gay couples embracing on Who Wants to be a Millionaire, and, unlike the early 1980s, when gay television and film characters were few and far between (and, more often than not, dying of AIDS) non-marginal gay characters in dozens of films, sitcoms, even Survivor. HBO specials with Sharon Stone, Oscar-winning performances by Tom Hanks, gay families in mainstream media products from American Beauty to Friends-none of these individually render Justice White's decoupling of sodomy from family untenable. But together they suggest a sea change in the way gay families function and are depicted in American cultural life.

And, of course, while there is debate within the queer community as to whether the family is a desirable social structure or not, ${ }^{185}$ many lesbians and gay men have not waited for straight society to allow them the luxury of defining their families; gay commitment ceremonies, bonds of kinship, and lifelong cohabitation are increasingly

181. For a survey of how state courts have occasionally adopted and occasionally rejected functionalist claims to the legitimacy of same-sex families, see Christensen, supra note 162, at 1391-99.

182. As one commentator observed:

Gay and lesbian family law. Even to have spoken the phrase as recently as a decade ago would have been only to speculate about the future .... There can be no doubt today that an identifiable body of family law has started to take shape to address the distinct problems of same-sex couples and parent-child relationships in lesbian and gay families.

See id. at 1414.

183. See Biskupic, supra note 76, at A1.

184. See Nan Alamilla Boyd, Shopping for Rights: Gays, Lesbians, and Visibility Politics, 75 DENV. U. L. REV. 1361, 1361 (1998) (citing an advertisement from the March 1998 issue of Out magazine).

185. See Kath Weston, The Politics of Gay Families, in Rethinking the FAmiLY: Some FEMINIst Questions 119, 122-23 (Barrie Thorne \& Marilyn Yalom eds., 2d ed. 1992) (discussing both sides of this debate). 
common on the American cultural landscape. ${ }^{186}$ Thousands of gay families, unlike reductios ad absurdum like the Belle Terre students or incestuous unions, fulfill the personal and social functions traditionally associated with the family, identified by a recent California task force as (1) maintaining the physical health and safety of family members by providing for their shelter, food, clothing, health care, and economic sustenance; (2) providing conditions for emotional growth, motivation, and self-esteem within a context of love and security; (3) helping to shape a belief system from which goals and values are derived, and encouraging shared responsibility for family and community; (4) teaching social skills and critical thinking, promoting lifelong education, and providing guidance in responding to culture and society; and (5) creating a place for recreation and recuperation from external stresses. ${ }^{187}$ To reiterate, the presence of these conditions is neither necessary nor sufficient for the existence of a constitutional family. But they are indicia that the self-definitions of gay families are not frivolous. They suggest that, for large segments of the population, gradually evolving social realities have created new, plausible definitions of "family," the determination of the parameters (and the carrying on of constitutive activities) of which is protected by the Fourteenth Amendment.

Hold on a moment, you might say: as much "progress" as there has been toward legitimizing gay families, it takes two to kulturkampf. There has also been a backlash: an increase in "family values" rhetoric, and congressional legislation, meant to exclude gay families and reaffirm that a "family" depends on marriage, that marriage depends on a man and a woman, and that "protection of the family" requires not only a ban on gay marriages but action against gays and

186. On gay commitment ceremonies, see generally TeSS AYERS \& PAUL Brown, THE Essential Guide to Lesbian and Gay Weddings (1994); Paul Horowitz \& Scott Klein, $A$ Ceremony of Commitment, in TwICE Blessed: ON BEING LESBIAN, GAY AND JEwISH 126 (Christie Balka et al. eds., 1989); Alternative Commitment \& Wedding Ceremonies Directory (visited Mar. 21, 2000) <http://www.ilovethisplace.com/iccr/directory> (on file with the Duke Law Journal) (providing a directory of commitment ceremony, gay parenting, and gay adoption resources); RainbowUnions.com (visited Mar. 21, 2000) <http://www.rainbowunions.com> (on file with the Duke Law Journal) (providing commitment ceremony resources).

187. See California Legislature, Planning a Family Policy for California, FIRST YeAR REPORT OF THE JOINT SELECT TASK FORCE ON THE CHANGING FAMILY 7-8 (June 1989), quoted in Treuthart, supra note 158, at 97; see also Bruce C. Hafen, The Family as an Entity, 22 U.C. DAVIS L. REV. 865, 894 (1989) (providing a functional definition of "family"). 
gay culture entirely. ${ }^{188}$ For many, "family" has become a code word for opposition to "alternative lifestyles" more generally. Indeed, this is the central irony of my argument: that "family," usually deployed as an anti-gay epithet, may be a key to recognizing a particular gay right. Many courts have declined to enforce parenting contracts between same-sex (ex-)partners, some on policy grounds. ${ }^{189}$ Gay men and lesbians are still the object of intense social hostility, ${ }^{190}$ and, belying the rhetoric that homosexuality is a choice free of any environmental or biological necessity, suicide rates on the part of gay teenagers remain high. ${ }^{191}$ For heaven's sake, gays can't even march in some St. Patrick's Day parades. It is also true that the "family" itself is an institution that is perceived by many to be threatened by gays and gay rights. Pat Robertson sees gay rights as "a radical plan to destroy the traditional family,"

188. On the Defense of Marriage Act and related legislation, see infra note 207 and accompanying text. Organizations that link an anti-gay political agenda with protection of the traditional family include the Family Research Council, see, e.g., How to Protect Your Children from Pro-homosexuality Propaganda in Schools (visited Mar. 21, 2000) <http://www.frc.org/infocus/ if $99 \mathrm{j} 1 \mathrm{hs} . \mathrm{html}>$ (on file with the Duke Law Journal), the Traditional Values Coalition, see, e.g., Foreign Services Launches an Attack on the Family (visited Mar. 21, 2000) <http://www. traditionalvalues.org/leg_wrap_afsa.html> (on file with the Duke Law Journal), and, most relevant to the material in this Essay, Coloradans for Family Values, which spearheaded the successful campaign for Colorado's Amendment 2. See Dodson, supra note 47, at 286-87 (describing the respondents' brief in Romer as depicting gays as "morally 'depraved persons' undermining traditional family values"); see also William N. Eskridge, Jr., Multivocal Prejudices and Homo Equity, 74 IND. L.J. 1085, 1093 (1999) (characterizing the arguments set forth by the family values organization as "hysterical and obsessional"). Stephen Carter has recently spoken pointedly on the subject of "protecting the institution of marriage." His view is that marriage is not something the state should be protecting, or even ratifying, and that what would protect the institution best would be if the state would simply stay out of it and let communities form binding marriage contracts on their own. See Stephen L. Carter, "Defending" Marriage: A Modest Proposal, 41 How. L.J. 215, 225 (1998).

189. See, e.g., Nancy S. v. Michele G., 279 Cal. Rptr. 212, 219 (Cal. Ct. App. 1991) (refusing to enforce a custody agreement between a lesbian couple because the non-biological mother was not a legally recognized parent); In re Alison D. v. Virginia M., 572 N.E.2d 27, $29-30$ (N.Y. 1991) (refusing to grant a lesbian partner standing to enforce a visitation agreement).

190. See Jane S. Schacter, Romer v. Evans and Democracy's Domain, 50 VAND. L. Rev. 361, 368-69 (1997) (citing studies and statistics).

191. See William B. Rubinstein, Cases and Materials on Sexual Orientation AND THE LAW 289 (1997) (reprinting PAUl GibSON, GAY AND LESBIAN YOUTH SUICIDE, HHS YOUTH SUICIDE REP. 110 (1989)).

192. Christensen, supra note 155, at 1720 (quoting Steve Daley, At This GOP Convention, Hate, Not Compassion, Was the Coin of the Realm, CHI. TRIB., Aug. 23, 1992, § 4 (Perspective), at 4 (quoting Robertson's remarks during the Republican Party Convention)). 
family law still reflects the traditional nuclear family model, ${ }^{193}$ even as such families only represent about a quarter of households today. ${ }^{194}$ The heterosexual, nuclear family may be a demographic minority, but it is still an ideological hegemony. Right?

Yes and no. The question is what the constitutional meaning of kulturkampf really is. My point has not been that the term "family" now has a wider single definition than before; rather, the point is that the term has multiple, hotly contested definitions, and that there are good arguments on both sides. Thus the question becomes narrower: whether the large portion of American society which believes gay families to be families can be declared constitutionally wrong, and on what grounds. In other words, the question is not which side is right but whether either side can be said, by the Supreme Court or by a legislature, to be wrong.

It should also be clear that the argument is not "I feel it is my family, therefore it is my family." Clearly, mere preference and a rationale to back it up are insufficient bases for defining a constitutional category. We cannot "really want" gay families to be (or not to be) families. Rather, there must be either a way to define the "family" in some objective manner, or a way to operate in the absence of such a definition. I want to suggest that looking at how the term is actually used by large swaths of American culture, recognizing that there is ideological (and even geographical) variation in "America," is such a way. It would exclude truly marginal relationships (incest, casual sex, etc.), because history-our lived history-counts. It matters that there are thousands of gay employees whose long-term partners receive disability benefits, that a lesbian couple can adopt a child together, and that there are gay members of Congress who have families and gay families on television. And it matters that, for example, there are no such benefits or public recognitions of incestuous or other such relationships. All of these things matter because they are history, and they are cultural practice. This is the difference between 1986 and 2000. Doubtless, in 1986, many gay men and lesbians felt a family bond as strongly as they do in 2000 . The constitutional difference is that their feelings are no longer personal idiosyncrasies. As a result of

193. See Mary Ann Glendon, The Transformation of Family LaW: State, Law AND FAMILY IN THE UNITED STATES AND WESTERN EUROPE 291-93 (1989); Christensen, supra note 162 , at 1302 .

194. See Christensen, supra note 162, at 1311 (citing census statistics). 
a long and unsteady change in American social behavior, they are sociological facts.

Now, one might object, isn't this non-decision really a decision in disguise? Really, doesn't saying that "a family may be a gay family," in fact impose a philosophical viewpoint? Worse yet, it may even impose a counterdemocratic, minority philosophical viewpoint on the majority. At the very least, it shuts off an important debate.

Although I will return to this subject in the conclusion, in fact, the philosophical laissez-faire position here is not for the Supreme Court to say, "A Family Is This, and Not That." Rather, the proper position here is for the Court to say, "A family may be this, and it may be that, and the state is not going to decide for you." The debates may continue to rage in all fora-public, private, secular, religious, and so on. It is even possible that the last fifteen years of cultural change can be reversed. But because today gay families clearly are "families" in actual, functional, societal terms, they are within the zone of protection envisaged by the Due Process Clause: no process can duly destroy a family.

Moreover, what "liberty" is being abridged by a judicial recognition that certain families may exist, and have the right to self-define? Only the right to ban. And this is a strange liberty. It's not exactly like the right to make up your own mind for yourself and exercise your freedom-it's the right to make up your mind for everyone else and to use the apparatus of the state to curtail their freedom. ${ }^{195}$ It's not like choosing the kind of value-world you want to live in-that anyone remains free to do, so long as they do not threaten with statesponsored violence those whose fundamental values, and personal life decisions, are different. The critical point in the argument is precisely that violence-that the state, in banning sodomy, would be attempting to coerce the definition and constitution of a "family." This it cannot do. All the Court is saying, in all these controversial constitutional law cases, is "Live and Let Live."

195. This is also, I think, the difference between my view of kulturkampf and that of William Eskridge, that "[a] key role for the judiciary is to resist Kulturkampf, and to help the political system repudiate the legacy of Kulturkampf." Eskridge, supra note 42, at 421. But what Eskridge has in mind appears to be the co-option of the apparatus of the state by the kulturkampf: sodomy carrying life sentences in jail or mental institutions, for example. See id. at 429-30. As noted in the Introduction, this is closer to what the term originally meant as used by Otto von Bismarck to refer to the state-backed effort to eradicate certain "foreign" aspects of the Catholic Church (and, in the American context, the fight against the Mormon Church). See id. at 420, 426-29. In my view, though, a cultural struggle includes but also extends beyond legal and political coercion. It includes social stigmatization, representations in cultural artifacts, and so on. 
Such folksy reasoning may seem distant from the principles of substantive due process, but in fact it is nothing more (or less) than a rephrasing of "the concept of ordered liberty" itself. To summarize:

1. All agree that decisions and actions that are part of "family life" are protected by the Fourteenth Amendment, although there is disagreement on exactly why that is so.

2. Whether gay families are really "families" or not is a subject of heated, sincere dispute, but it must be beyond dispute-in 2000, if not in 1986-that many people believe that they are, that they function as families in American society, that they obtain many family-like benefits from the state and private actors, and so on.

3. The decision as to whether gay "families" are families is itself a decision intimately associated with basic beliefs about the family, and the state is prohibited by the Fourteenth Amendment from making that decision for an individual: the state cannot define a right away by defining the terms associated with that right.

4. Because it is apparent from our society's use of the term "family" that gay families are plausibly families, and because the state cannot define them otherwise, the state may not prohibit the constitutive acts of gay family life, including sodomy.

That is the argument. Is the ending somewhat amorphous-television shows having constitutional significance? Perhaps it is, but it is a far more democratic amorphism than a judge's gloss on "traditional morality," whatever that is. The question is simply what basis the Court can have for including or excluding gay families, if tradition cannot automatically trump reasoned judgment in the definition of terms. And what is tradition, in any event, but the social practices of the hoary past-Leave it to Beaver instead of Dawson's Creek. Law listens to culture at least as much as it regulates it. That our culture is presently struggling with the definition of the "family" ought to mean that the power apparatus of the state cannot intrude upon such an intimate and private area. This is what substantive due process is all about. 


\section{Stare Decisis and Bowers II}

Before concluding, we should consider this last point-how and whether historical change can overturn settled Supreme Court decisions-both because stare decisis is a non-trivial challenge to Bowers II and because it actually helps shed light on the foregoing analysis.

"[T]he very concept of the rule of law underlying our own Constitution requires such continuity over time that a respect for precedent is, by definition, indispensable." ${ }^{196}$ So said the Court in Casey, perhaps the most famous case in history about the jurisprudential doctrine of stare decisis, which means literally "let the decision stand." Citing a number of earlier cases, Casey set forth four factors a court should consider in determining whether a prior constitutional decision of the Supreme Court could be overturned:

[If] the rule has proven to be intolerable simply in defying practical workability ... whether the rule is subject to a kind of reliance that would lend a special hardship to the consequences of overruling... whether related principles of law have so far developed as to have left the old rule no more than a remnant of abandoned doctrine... or whether facts have so changed, or come to be seen so differently, as to have robbed the old rule of significant application or justification. $^{197}$

Applying the Casey taxonomy to Bowers underscores how historical change has rendered the old case something less than good law. The first three conditions point toward affirmance: Bowers has not proven unworkable; it has not engendered any particular reliance one way or the other (at least not on the scale of Roe); and, though Bowers's doctrinal soundness may be debated, it is hardly Plessy or Lochner. It is the fourth point, though, which is critical, and which has animated the argument in this Essay: the facts have changed. By "facts" we mean not (just) that sentiments have changed or that political correctness has grown; rather, given societal realities, it is factu-

196. Planned Parenthood v. Casey, 505 U.S. 833, 854 (1992).

197. Id. at 854-55 (internal citations omitted). In applying this doctrine to Roe, the Casey majority concluded that Roe was, though controversial, not "unworkable"; decided that there was considerable reliance on Roe both specifically and generally; identified aspects of Roe which were, to varying degrees, still doctrinally viable; and limited the changes in facts to new times when the fetus is viable and when the mother's life is in danger. Casey went on to conclude that, in contrast with Lochner v. New York, 198 U.S. 45 (1905), and Plessy v. Ferguson, 163 U.S. 537 (1896), Roe carries no "terrible price" and that, on the contrary, overruling it would shake the faith of the American people in the Court itself. Id. at 862-64. 
ally incorrect to say that "homosexual sodomy has no connection to family life." Bowers's structure may remain, but its foundations have shifted-recall, Justice White's whole discussion of sodomy law took place only because protecting sodomy would mean creating a "new" right rather than invoking one within existing precedents on family relationships. ${ }^{198}$ Now, that condition has changed, and Bowers's validity along with it.

That the doctrines of stare decisis and the parameters of constitutional interpretation converge so neatly is not coincidental. The relatively conservative attack on Bowers that I have tried to sketch here is premised on the notion that new rights lurking in the Fourteenth Amendment are few and far between. But times change, selfconceptions evolve, and the meanings even of concepts as fundamental as the "family" shift with time. These changes are irrelevant only if the Supreme Court sits in an ivory tower, foreclosing new nomian possibilities by plugging its ears with old definitions. Romer did not overrule Bowers. But America did.

\section{DOES ANYBody CARE?}

So, do we care? If the foregoing analysis is right and Bowers should fall by its own logic, should the Lambda Legal Defense Fund file suit tomorrow? Should the Family Research Council send out an alarming fund-raising letter?

On the pure practical consequences of Bowers, I think the answer is a weak yes. Of course, on the most narrow grounds, Bowers II is moot: as noted earlier, the statute at issue has already been declared unconstitutional by Georgia's Supreme Court. ${ }^{199}$ On slightly wider grounds, invalidating sodomy laws would have some effect, because they are still enforced by many municipalities and remain a potentially terrorizing tactic of state intervention in intimate human life. ${ }^{200}$ Bowers II might also reduce the ease with which courts dismiss Romer/Equal Protection challenges by making Bowers/Due Process arguments, as discussed in Part One, although, in the years since Bowers, gay rights advocates have shifted their turf from removing the persecution of homosexuality to removing the persecution of homosexuals-from Bowers to Romer, in other words. The battlefields

198. See supra notes 17-22 and accompanying text.

199. See Powell v. State, 510 S.E.2d 18, 26 (Ga. 1998).

200. See Halley, supra note 16, at 1731-33; Hammack, supra note 41, at B1; Nathan, supra note 40 , at 16 . 
are no longer in the bedroom; they are at the office, in the military, on the television, and in the hospital.

But if it was in the areas of society and culture that Bowers mattered the most, it is in those same arenas that Bowers II seems so irrelevant. The whole point of the previous part is that societal attitudes towards gay families have changed, and that Bowers II would be following, not leading, social change. This, presumably, is what both a conservative and a pro-democracy liberal would want the $\mathrm{Su}$ preme Court to do, but it means that the actual social impact of repealing Bowers may be slight. Moreover, whatever impact Bowers II would have, I think it is fair to say-though impossible to prove-that it would be far less important than the kulturkampf being carried on in America's cultural and religious communities. "Progressives" are tolerant of homosexuality and gay people; "traditionalists" are not. Known sodomizers (criminals!) march yearly in most of America's big cities; suspected queers are beaten up in small towns. The law has nothing to do with it. Ironically, the very societal factors that make Bowers bad law under Casey make it more or less irrelevant. Really, given the current disconnect between quaint, homophobic Bowers and twenty-first-century popular culture, overturning the case might say more about the Supreme Court than about gays and lesbians.

Justice Scalia was right: Romer was about a kulturkampf-not a legal debate. And as that kulturkampf has progressed, the strictly legal consequences of this set of cases have diminished in number and importance. Thus, I want to spend these last few pages on the $k u l$ turkampf itself, or more particularly, on the interaction between our evolving American attitudes towards homosexuality and "the law." First, I want to return to a thorny objection that stems from my analysis: namely, whether a Supreme Court case overturning Bowers is in some way antidemocratic or coercive or whether what we have now, with gay rights being the subject of a public debate, is a precious case of participatory democracy in action, and whether an intrusion by the Court would subvert that debate. I argue, along the lines of Robert Cover, that the Court's allowance of multiple nomoi, or legalconstitutive communities, would foster democratic discourse rather than squelch it, and, because of the difference between tolerance and acceptance, would have no effect on the debates regarding gay marriage. Second, the Bowers/Romer nexus highlights an important and sad disconnect between law and the kulturkampf: the inability of our legal debate to address the moral questions at the heart of gay rights, questions of biology and legalism, of religion and community. Since I 
can imagine no more weighty questions than these, it will be with their consideration that the Essay will end.

\section{A. Democracy 102: Some Notes on Yelling, Nomoi, and Gay Marriage}

I have suggested that a basically conservative reading of substantive due process leads to the voiding of a potentially popular piece of legislation due to contention surrounding its key terms. One might easily object that to do so short-circuits the conscience-searching process of important political legislation-a process that is part and parcel of the kulturkampf under discussion. This is the "countermajoritarian difficulty" amplified: the very fact that something is being heavily debated may lead to a judicial act that squelches debate. Surely, even if we grant that the Court as a countermajoritarian institution has its place in American democracy, we must all agree that public debate, even rancorous debate, on a subject as morally incendiary as homosexuality is a good thing, and that this is the worst time for an elite institution to tell everyone to stop yelling.

I am all for continued yelling. Indeed, I would like more and better yelling, as I will discuss in the next section. And that is why it is crucial to remember that Bowers II would not end debate, and would not say sodomy is right, good, or healthy. Indeed, the state would still be able to curtail public displays and recognition of behaviors it finds objectionable. Bowers II would only remove the apparatus of the state and its jails from enforcing a majoritarian vision of goodness in private family matters. Why would this squelch debate, which after all is more properly one of morality than of legality? If anything, Bowers II would make the debate more vigorous, because it would allow for more self-definition and remove the circular argument that something is bad because it is illegal, illegal because it is bad, and so on. In familiar terms of liberal social justice, it returns the state to where it ought to be-to a position of neutrality with respect to differing conceptions of the good life. ${ }^{201}$ In simpler terms, to repeat, it lives and lets live.

Those of us trained in (or forced to endure) legal-economic thinking sometimes forget that there is a difference between abridg-

201. See Bruce A. Ackerman, Social Justice in the Liberal State 10-11 (1980); RONALD DWORKIN, Liberalism, in A MATTER OF PRINCIPLE 181, 191 (1985); H.L.A. HART, LAW, LiberTy, AND Morality 4-6 (1963); ANDREW Sullivan, ViRTUALly Normal: AN ARgument About HomoseXuality 138-44 (1995). 
ing the right of one party to act and abridging the right of another to prohibit the first party from acting. Theoretically, there is no difference at all, absent whatever quantifiable difference in utility that exists between, say, your right to play your radio loud and my right to live in peace and quiet_and those "black box" differences are hard to measure. Your right to listen to music, and my right to stop you from doing so so that I can read, are just two interests which must be reconciled by setting up some kind of regime to allocate the right of noise. But is this really true in the case of anti-sodomy laws? Some people may suffer harm by having to put up with morally objectionable acts of sodomy taking place in their neighborhood. But is harm, offending of sensibilities, really equal to the harm suffered by a gay man who is forbidden from obtaining the same sexual and emotional fulfillment as a straight man?

Yes, pluralism does impose costs. Moving from the language of law and economics to that of Robert Cover, we might say that pluralism restricts the ability of the majority to create the kind of "normative universe" they want to live in. ${ }^{202}$ But let's pursue the Cover line of thinking more fully. At the same time that pluralism diminishes one majority's attempt to create a normative universe, it allows the creation of many such universes. More precisely, Bowers II removes the threat of force to impose one "imperial" nomos-backed up by force, with the purpose of maintaining an orderly society-and allows individual communities to construct several "paideic" ones dependent not on force but on communities of meaning, such as religious communities. $^{203}$

True, the unlimited proliferation of legal meaning is impossible within a cohesive society, and limiting the power of "imperial" states is in some ways jurispathic. But inasmuch as sodomy laws are truly based on "morality," they are a case of one, hegemonic nomos coopting the apparatus of the state to convert its paideic normative universe into an imperial one-to move from the church house to the state house. Prohibiting this move, really, is the only "cost" imposed by pluralism. Moral censure, media campaigns, promises of hellfire, philosophical reasoning, recourses to Darwin, immunological theodicy, stories of Roman decadence, pictures of lovely straight children, social advancement, parental love-all of these remain tools of one opposed to homosexuality. He just doesn't have the jailhouse.

202. Cover, supra note 10 , at 6-7.

203. Id. at 12-13. 
Nor does the sketch I have drawn of Bowers II imply any kind of societal approval of homosexuality-in particular, gay marriages. Interesting philosophical analyses of the issue have begun to work their way into the literature, ${ }^{204}$ and I think there are compelling policy arguments in favor of such recognition ${ }^{205}$-although I also agree with Richard Posner that for the Supreme Court to coerce states to recognize gay and lesbian marriage, would be an unprecedented act of countermajoritarianism. ${ }^{206}$ There are even more compelling arguments that Congress's effort to pre-empt such recognition, i.e., the Defense of Marriage Act ("DOMA"), is unconstitutional. ${ }^{207}$ And if the recent events in Vermont show us anything, it is that a court decision on gay marriage or gay rights need not cut off debate; on the contrary, it can invite and stimulate it.

204. See, e.g., John G. Culhane, Uprooting the Arguments Against Same-Sex Marriage, 20 CARDOZO L. REV. 1119, 1125 (1999) (concluding that opposition to same-sex marriage has its roots in conflation of biology and gender); John Finnis, The Good of Marriage and the Morality of Sexual Relations: Some Philosophical and Historical Observations, 42 AM. J. JURIS. 97, 126-34 (1997) (arguing that only heterosexual marriage can actualize the "good" of marriage by committing both partners to a form of sexuality that connects the sex act to a permanent, procreative bond between them).

205. See, e.g., William N. Eskridge, Jr., The CaSe for SAme-SeX Marriage: From SEXUAl LiBERTY TO CIVILIZED COMMITMENT passim (1996) (providing policy and constitutional arguments in favor of same-sex marriage). Chapter three of Professor Eskridge's book identifies, and debates, the many thinkers within the gay community who oppose gay marriage for a variety of reasons. See id. at 51-85; see also Linda S. Eckols, The Marriage Mirage: The Personal and Social Identity Implications of Same-Gender Matrimony, 5 MICH. J. GENDER \& L. 353, 407 (1999) (arguing that thrusting same-sex marriage on the nation "is simply too much at one time, for gay men and lesbians, and for society"); Nancy D. Polikoff, We Will Get What We Ask For: Why Legalizing Gay and Lesbian Marriage Will Not "Dismantle the Legal Structure of Gender in Every Marriage”, 79 VA. L. REV. 1535, 1536-37 (1993) (opposing efforts to make the right to marry a priority for the lesbian and gay rights movement).

206. See Richard A. Posner, Should There Be Homosexual Marriage? And If So, Who Should Decide?, 95 Mich. L. REv. 1578, 1584-85 (1997). This is also Cass Sunstein's concern in Homosexuality and the Constitution, 70 IND. L. J. 1, 27 (1994).

207. On the unconstitutionality of the DOMA, see Melissa Rothstein, The Defense of Marriage Act and Federalism: A States' Rights Argument in Defense of Same-Sex Marriages, 31 FAM. L.Q. 571, 577-82 (1997) (discussing DOMA and the Full Faith and Credit Clause); Scott Ruskay-Kidd, The Defense of Marriage Act and the Overextension of Congressional Authority, 97 COLUM. L. REV. 1435, 1482 (1997) ("DOMA short-circuits the Full Faith and Credit Clause, conflicts with basic understandings of federalism, and strays from the substantive commandment of the constitutional text itself."); Sherri L. Toussaint, Defense of Marriage Act: Isn't it Ironic . . . Don't You Think? A Little Too Ironic?, 76 NEB. L. REV. 924, 964-78 (1997) (advancing several arguments against DOMA's constitutionality); Laurence H. Tribe, Toward a Less Perfect Union, N.Y. TIMES, May 25, 1996, at E11 (discussing DOMA and the Full Faith and Credit Clause). On DOMA's effect on conflicts law, see generally Stanley E. Cox, DOMA and Conflicts Law: Congressional Rules and Domestic Relations Conflicts Law, 32 CREIGHTON L. REV. 1063 (1999). 
However sympathetic I am to these points, I do want to call attention to the distinction between obtaining a license from the state to change one's public status and simply pursuing the life one wishes to lead. In the Bowers II rationale I have sketched, the Supreme Court remains agnostic on the merits of gay families: it only recognizes that such families may reasonably be considered families by some, and that that act of self-definition is itself protected by the Fourteenth Amendment. In contrast, gay marriage makes an affirmative statement on the part of the state. Gay marriage is not "live and let live"; it is a public, communal institution which depends on the community for definition. The difference is between tolerating something that may be morally reprehensible and approving of that something. It should not be too much of an overstatement to label that difference the fundamental lever of pluralistic democracy.

There is a second, more subtle, difference between gay marriage and Bowers II: the nature of the right in question, and the attendant terms to be defined. The right to marry as recognized by the Supreme Court is something that exists as part of the rights implicit in the concept of ordered liberty-but not necessarily the right to define the term "marry." This makes sense for the reasons just discussed: "marriage" is a term whose definition is more public than private, less a matter of pluralism and more a matter of community consensus. While the Fourteenth Amendment may yield a right to determine the contours of one's family (within the bounds of reason), no affirmative state obligations flow from that right precisely because it is a matter of "private concern." "A right to privacy" may cut both ways. So while the argument in this Essay does not foreclose arguments for gay marriage, it does not advance them either. Because of the nature of "privacy," marriage is not the same, constitutionally speaking, as the family-something which, in the non-constitutional realm, thousands of unmarried couples, gay and straight, already know.

\section{B. Engaging with the Kulturkampf: Adjudication and Black Boxes}

The argument of this Essay has been that courts, particularly the Supreme Court, must listen to the kulturkampf in determining the meaning of critical constitutional terms. And yet, much of what the Court will hear is nonsense. For anyone familiar with queer theory or anyone who even happens to know many gay people, hearing much mainstream legal and political debate about homosexuality is like listening to sixth graders discussing Shakespeare: homosexuality is "un- 
natural," sodomy is a "sin," or, alternatively, "it's my life," or, "we're here-we're queer-get used to it." Of course, sloganeering is part of politics. But each of these claims actually contains a package of constitutionally relevant suppositions: that there is a natural way of humans to be (from which some choose to deviate), or that America must tolerate something it morally disdains, simply as a matter of psychological maturity. Maybe it's fine for politicians and demagogues to just sell such claims to their audiences, without any real analysis of the underlying issues that are implicated by them, but what about when these claims are presented to a court? What does "listening to the kulturkampf" mean then?

As Richard Posner has recently demonstrated in Sex and Reason, ${ }^{208}$ it is possible for a jurist to break through the black boxes of "morality," deployed by both sides of the gay rights debate, and meaningfully adjudicate the claims within. ${ }^{209}$ I want to argue that to do so is necessary for courts to do their jobs. Sifting fact from fantasy is not an intrusion of law into the domain of morality, but is part and parcel of what the law must do, particularly in a contentious area such as the gay rights kulturkampf, because competing "moral" rationales often must be adjudicated. Let us suppose, for example, that Justice Scalia was right that the Coloradans who voted for Amendment 2 authentically believed that gay people posed a threat to the maintenance of traditional, straight nuclear families. Would they not then be constitutionally justified in taking steps to limit the rights of gays?

The answer to that question simply must penetrate the black box of "morality" because, as Loving must tell us, a state's "moral" choice can sometimes be constitutionally wrong. Suppose, for instance, sexual orientation is like race-not a choice of lifestyle, as in the rhetoric of the Right, but a biological fact about a human being. If this is so (the view known as "essentialism"), then the next Colorado would have a very difficult argument to make: that it is entitled to place a disability on a group of people because of the way they were born. If, on the other hand, sexual orientation is not like race but rather is something "chosen," or at least conditioned by environmental factors that we can control (the view known as "constructionism" or "con-

208. RichARD POSNER, SEX AND REASON (1992).

209. See id. passim; see also William N. Eskridge, Jr., A Social Constructionist Critique of Richard Posner's Sex and Reason: Steps Toward a Gaylegal Agenda, 102 YALE L.J. 333, 384 (1992) (departing from Posner's libertarian approach, because the laws that gays and lesbians seek "will enlist the state as an ally in [the] struggle against social oppression"). 
structivism"), ${ }^{210}$ then the next Colorado has a different, and to my mind easier, argument to make-namely, that some fundamental choices, even though they are fundamental, may invite statesponsored disabilities, because just as a majority may want to discourage people from "choosing" to rob or steal, so too may it discourage people from "choosing" to threaten the nuclear family (if indeed there is evidence that gay people do so). Likewise, an opponent to an Amendment 2 has different burdens to carry, depending on the nature of homosexuality: to argue against discrimination based on someone's innate characteristics is part and parcel of American liberalism. To argue against discrimination based on someone's fundamental lifestyle choice, while it may be an important argument for gay people to make, ${ }^{211}$ is different from, and surely harder than, saying that orientation is "like race." Constructivism is generally the fashion in gay rights circles, since it helps problematize basic Western assumptions about gender and hierarchy; ${ }^{212}$ but if sexuality is constructed, why not favor some constructions over others? Even worse: that a characteristic be "immutable" is one of the traditional requirements for heightened scrutiny in the equal protection context. ${ }^{213}$ What then?

To put it another way: Justice Scalia, in his Romer dissent, noted that law schools may reject a job applicant

because the applicant is a Republican; because he is an adulterer; because he went to the wrong prep school or belongs to the wrong country club; because he eats snails; because he is a womanizer; be-

210. On essentialism and constructivism, see generally Daniel R. Ortiz, Creating Controversy: Essentialism and Constructivism and the Politics of Gay Identity, 79 VA. L. REV. 1833 (1993).

211. See Jonathan Pickhardt, Note, Choose or Lose: Embracing Theories of Choice in Gay Rights Litigation Strategies, 73 N.Y.U. L. REV. 921, 951-64 (1998) (suggesting the use of legal arguments under a choice-based theory gay identity).

212. Social constructionism is often the implicit moral claim behind surveys of unfamiliar sexual-social practices such as William Eskridge's examination of same-sex unions in other cultures. The implicit argument is that these practices prove that universalist claims that marriage is "naturally" or "essentially" heterosexual are false, and are merely an attempt to ground a particular social practice in a non-existent fact of nature. The very nature of "gay" and "straight" may be socially constructed as well. See POSNER, supra note 208, at 38-60 (positing stages in the evolution of sexual norms); Milton C. Regan, Jr., Reason, Tradition, and Family Law: A Comment on Social Constructionism, 79 VA. L. REV. 1515, 1521 (1993).

213. See Yoshino, supra note 47, at 493-94 (discussing Watkins v. United States Army, 837 F.2d 1428 (9th Cir. 1989)). Yoshino himself does not agree with the principle that race or sex is biologically determined, but focuses his remarks on immutability to a critique of how the term is deployed in public discourse. See id. at 509-19. 
cause she wears real-animal fur; or even because he hates the Chicago Cubs. But if the interviewer should wish not to be an associate or partner of an applicant because he disapproves of the applicant's homosexuality, then he will have violated the pledge [of acceptance of homosexuals] which the Association of American Law Schools requires. $^{214}$

Once more, are gays more like blacks, or more like Republicans? The question, and the answer, matter constitutionally. Nor can they simply be ignored in favor of a rationale which may not be defensible. The Bible and "traditional morality" were put into useful service by anti-miscegenation advocates, pro-slavery advocates, and a host of other interest groups we now recognize as being bigots; the question is whether the claims of such traditions can be rationally defended in a democracy. If sexuality is "like race," an unchosen characteristic of a human being, then it is hard to see much of a distinction. On the other hand, if homosexuality really is a choice, like "being a Republican," what distinguishes it from other choices that we regulate all the time? What separates it from the reductios ad absurdum that opponents of gay rights sometimes invoke-bestiality, incest, et cetera? How $d o$ we distinguish between them without drawing more arbitrary lines of the "normal"? These are not only private questions of selfdefinitions; they are public, constitutional questions as well.

Just adjudication requires evidence, not a concealing rhetoric of deference to "morality." To be sure, there is evidence on both sides. There is evidence that our sexual orientation is determined by our cultures-other societies had no concepts of "gay" or "straight" as we know them today, and many men and women in those societies engaged in what we would consider to be homosexual behavior, but were never considered to be "queer" in any way. And yet there is evidence that our sexual orientation is determined by our genes-indeed, the size of the anterior hypothalamus may have constitutional import. ${ }^{215}$

214. Romer v. Evans, 517 U.S. 620, 652-53 (1995) (Scalia, J., dissenting).

215. One of the interstitial nuclei of the anterior hypothalamus, believed to control sexual activity, has been shown to be smaller in homosexual men than in straight men, suggesting a biological origination of homosexuality. See Simon LeVay, A Difference in Hypothalamic Structure Between Heterosexual and Homosexual Men, 253 SCIENCE 1034, 1035 (1991). On scientific and social-scientific evidence for essentialism and constructionism, see Susanne M. Stronski Huwiler \& Gary Remafedi, Adolescent Homosexuality, 33 REV. JUR. U.I.P.R. 151, 15559 (1999). 
Evaluating such evidence is what judging is all about. For an academic to bracket these disputes as outside her area of interest is, perhaps, defensible. But, echoing Posner's critiques here, for a jurist to think that these debates are irrelevant is irresponsible: they are necessary to ascertain what theory of rights, constitutional or otherwise, are to undergird protection (or non-protection) for gays, and to adjudicate the moral claims presented by legislatures. ${ }^{216}$ Like it or not, the hypothalamus does matter. Without entering into debates about either the nature of homosexuality or the parameters of "fundamental" choices about one's identity in a liberal state, again, this is but one example of the kinds of debate necessary for meaningful adjudication of gay rights cases, it is hard to respond meaningfully to a non-coercive regime that aggressively promotes heterosexuality and refuses to legitimize other "choices." To be sure, gay people can point to all sorts of wonderful contributions they have made to politics, art, music, dance, sports, and other areas of society. But surely it is within a community's collective rights to strive for the society they wish to live in. And if that society is overwhelmingly straight, what's wrong with that?

Law, in evaluating these scientific and social-scientific claims, is not "intruding" upon some sort of autonomous zone of societal debate, moral theory or scientific fact. Rather, law acts as the appropriate mediator between "moral" claims which depend in part on sociology, physiology, and other disciplines for their support, and whose theoretical underpinnings may trigger constitutional questions. Of course, moral opinions are different from ordinary opinions-not the least because they can be changed through moral suasion, an imperative element of our political discourse. But to deny that "moral" opinions also depend on facts is to render them private opinions utterly divorced from public discourse-miniature "black boxes" impervious to debate. Moreover, evoking Cover once again, moral opinions are, when translated into law, backed up with violence. ${ }^{217}$ It's a shame when someone misreads Shakespeare. But it's something a bit more serious than that when a lesbian couple spends days trying to get their legally adopted children on their health insurance policies,

216. I am reminded here of Kenji Yoshino's anecdote about an interview with a federal judge who had just heard a controversial gay rights case, but who was unaware of the use of the pink triangle either by the Nazis or by latter-day gay activists. See Yoshino, supra note 56, at 1753.

217. See generally Cover, supra note 10; Robert M. Cover, Violence and the Word, 95 YALE L.J. 1601 (1986). 
or a gay couple waits years to adopt a child whom a far-less-fit straight couple could have adopted within a few months. These people are the ones who have to be told that their families, with drawings magnet-stuck to the refrigerator and a lawn in need of mowing, are not "families" because other people either cannot conceive of them or deem them to be "unnatural." If the state chooses to use its coercive power to enforce a moral choice, the reasons behind such a choice, and the evidence for those reasons, are not issues of private morality or theoretical interest. They are the difference between a justified public law and a contemptible act of violence.

Doubtless, the law is a contentious forum for the debating of such difficult and contentious issues, and some might wish that it would just "keep out of it." Many on the Left have feared the entry of an uneducated, conservative judiciary into matters they think should be beyond its control. Many on the Right have feared the intrusion of liberal judges into matters of their personal morality. But the lesson of what I have called the self-destruction of Bowers is that the law cannot be deaf to the changes in society, including changes in society's understanding of nature, which alter the terms of legal debate. The law should not be mute either.

For now, Bowers v. Hardwick remains the Supreme Court's last authoritative statement on the legal proscription of gay sexual activity. Romer v. Evans did not overturn it; if anything, much of Bowers was solidified by the later case's avoidance of anything that might be seen to replace its core holdings. But Bowers has not kept pace with the times. The kulturkampf of which Justice Scalia spoke in his Romer dissent has engulfed America, with consequences in America's media, schoolhouses, offices, and households.

These cultural changes have altered terms of the debate-one term, "family," in particular. And yet change is nothing new under the sun: for all its importance as an American institution, the meaning of the "family" has always evolved, and will likely continue to do so. Though we are not likely to agree on what constitutes a "family" any time soon, even within the carefully patrolled boundaries of substantive due process jurisprudence and stare decisis, these changes matter. There is no need for innovative readings of the Constitution or expansions of notions of personal liberty to see how Bowers v. Hardwick has ceased to be good law. The Supreme Court needs only to get real. Speaking not in some vague, abstract way and not in the fictional language of yesteryear but speaking concretely, sociologically, and 
realistically, gay families are families. That may not have been true in 1986. But it is true now. Bowers is obsolete. 